\title{
Changes in gene expression following cardiac pacing-induced delayed cardioprotection in
} the canine heart

\author{
PhD Thesis
}

Mária Kovács

Supervisor: Prof. Dr. Ágnes Végh

Department of Pharmacology and Pharmacotherapy

Albert Szent-Györgyi Medical Center

University of Szeged, Hungary 


\section{LIST OF PUBLICATIONS}

\section{Full Papers}

1. Kovács M, Papp R, Varga-Orvos Z, Ménesi D, Puskás LG, Végh A. Changes in gene expression following cardiac pacing-induced delayed cardioprotection in the canine heart. Acta Biol Hung. 2010 Dec;61(4):434-48.

2. Mária Kovács, Márton Gönczi, Edina Kovács, Ágnes Végh. Time course analysis of cardiac pacing-induced gene expression changes in the canine heart. Mol Cell Biochem. 2013 Jan;372(1-2):257-66. doi: 10.1007/s11010-012-1467-8.

\section{Abstracts of oral presentations}

3. Kovács M, Dr. Papp R, Puskás L, Végh Á. A késői prekondícionálás hatása a génexpressziós változásokra kutya szívizomban. Magyar Kardiológus Társaság Kongresszusa, 2009

\section{Abstracts of poster presentations}

4. Kovács M, Papp R, Puskás L, Végh Á. A késői prekondícionálás hatása a génexpressziós változásokra kutya szívizomban Magyar Élettani Társaság LXXIII. Vándorgyülése, 2009

5. Kovács M, Papp R, Ménesi D, Puskás L, Végh Á. Changes in gene expression following cardiac pacing-induced delayed cardioprotection in the canine heart. 20th World Congress of the International Society for Heart Research (ISHR), 2010. Journal of Molecular and Cellular Cardiology 2010 48(5): S102

6. Kovács M, Gönczi M, Végh Á. Changes in gene expression following rapid cardiac pacing in the canine heart. XXX. European Section Meeting of the International Society for Heart Research (ISHR), 2011.

7. Kovács M, Gönczi M, Seprényi Gy, Végh Á. Gene expression changes in the canine heart following rapid cardiac pacing 75th Anniversary of Albert Szent-Györgyi's Nobel Prize Award, 2012. 


\section{Other publications}

8. Tiwari V, Oh MJ, Kovacs M, Shukla SY, Valyi-Nagy T, Shukla D. Role for nectin-1 in herpes simplex virus 1 entry and spread in human retinal pigment epithelial cells. FEBS J. 2008 Nov;275(21):5272-85. Epub 2008 Sep 17.

9. Akhtar J, Tiwari V, Oh MJ, Kovacs M, Jani A, Kovacs SK, Valyi-Nagy T, Shukla D. HVEM and nectin-1 are the major mediators of herpes simplex virus 1 (HSV-1) entry into human conjunctival epithelium. Invest Ophthalmol Vis Sci. 2008 Sep;49(9):4026-35.

10. Kavouras JH, Prandovszky E, Valyi-Nagy K, Kovacs SK, Tiwari V, Kovacs M, Shukla D, Valyi-Nagy T. Herpes simplex virus type 1 infection induces oxidative stress and the release of bioactive lipid peroxidation by-products in mouse P19N neural cell cultures. J Neurovirol. 2007 Oct;13(5):416-25.

11. O'Donnell CD, Kovacs M, Akhtar J, Valyi-Nagy T, Shukla D. Expanding the role of 3-O sulfated heparan sulfate in herpes simplex virus type-1 entry Virology. 2010 Feb 20;397(2):389-98. doi: 10.1016/j.virol.2009.11.011.

12. Papp R, Gönczi M, Kovács M, Seprényi Gy, Végh Á. Gap junctional uncoupling plays a trigger role in the antiarrhythmic effect of ischaemic preconditioning. Cardiovascular Research, 2007 jun 1; 74(3): 396-405.

13. Gönczi M, Papp R, Kovacs M, Seprenyi Gy, Vegh A. Modulation of gap junctions by nitric oxide contributes to the anti-arrhythmic effect of sodium nitropusside? Br J Pharmacol 2009 May; 156(5):786-93

14. Juhász L, Kiss A, Nyeso E, Kovács M, Seprényi G, Kaszaki J, Végh A. Is there a trigger role of peroxynitrite in the anti-arrhythmic effect of ischaemic preconditioning and peroxynitrite infusion? Eur J Pharmacol. 2011 Sep 30;667(1-3):306-13. doi: 10.1016/j.ejphar.2011.06.010.

15. Gönczi M, Kovács M, Seprényi G, Végh A. The involvement of gap junctions in the delayed phase of the protection induced by cardiac pacing in dogs. Clin Sci (Lond). 2012 Jul;123(1):39-51. doi: 10.1042/CS20110501. 


\section{SUMMARY}

Understanding the mechanism behind the cardioprotection induced by preconditioning might provide a new therapeutic tool against the life threatening ventricular arrhythmias that often lead to sudden cardiac death.

Therefore in Study I, we aimed to investigate gene expression changes following ischemia and reperfusion in dogs subjected to rapid right ventricular cardiac pacing 24 hours previously by a genome-wide approach using cDNA microarray analysis. We also aimed to examine the transcription rate of 45 additional genes which have already been suggested to be involved in ischemic PC but little is known about their role in the cardiac pacing induced antiarrhythmic protection. Furthermore, in Study II, 29 genes were selected to explore the time course changes of gene expressions over 24 hours, which elapses between rapid cardiac pacing and the ischemia/reperfusion period.

In Study I, we have identified 23 genes with altered expression; some of these, for example, MEF2A (involved in angiogenesis) or mAKAP (an anchoring protein), were firstly demonstrated to be significantly up-regulated in response to preconditioning.

We have proved that rapid right ventricular pacing alters the expression of genes involved in the delayed protection. In Study I, 6 out of 45 genes exhibited significant down-regulation and 16 showed up-regulations in response to ischemia and reperfusion, compared with the control dogs. Among these, genes encoding different proteins, such as NO producing enzymes, heat shock proteins, members of the survival signaling pathways or pro-apoptotic factors showed the most marked changes. In Study II, we have proved that pacing induces time-dependent alterations in the expression of the 29 genes examined. Immediately after the cessation of pacing, 8 genes showed significant up-regulation and 6 significant down-regulation. After these initial changes, some of these early up- or down-regulated genes either remained unchanged or showed a biphasic transcriptional pattern; i.e. after an initial change in their transcription these genes were normalized to the mRNA level of the unpaced hearts but their expression started to change again at later time points. There were also genes, such as those encode eNOS and iNOS, which exhibited significant up-regulation only $12 \mathrm{~h}$ after the pacing stimulus. The resultant increase in eNOS protein content and activation certainly contributes to an increased NO production, to which we attribute an important role in late phase of the protection. We are aware that changes at gene expression level do not always reflect changes at protein level, nevertheless the present results provide evidence for gene expression changes following cardiac pacing, and when the antiarrhythmic protection is observed. 


\section{TABLE OF CONTENTS}

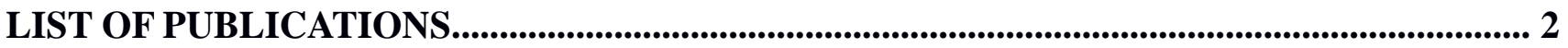

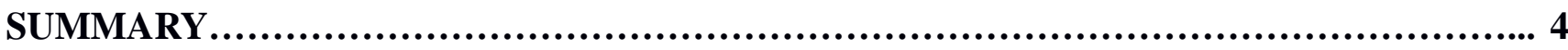

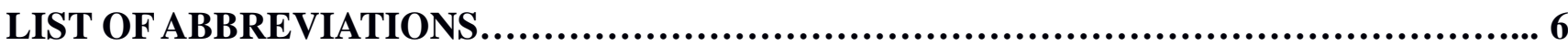

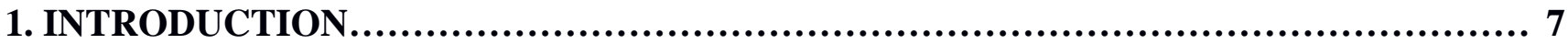

1.1 The antiarrhythmic effect of ischemic preconditioning and rapid cardiac pacing............ 7

1.2 Mechanism of the early protection induced by preconditioning $\ldots \ldots \ldots \ldots \ldots \ldots \ldots \ldots \ldots \ldots$

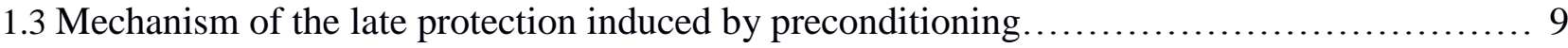

1.4 Mechanism of late antiarrhythmic protection induced by rapid cardiac pacing................ 11

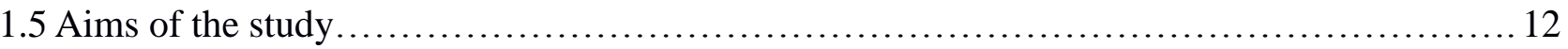

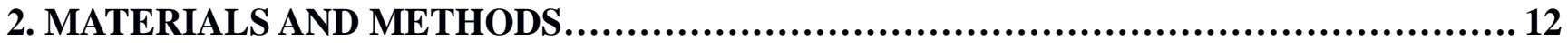

2.1 Experimental protocols and surgical interventions........................................ 12

2.1.1 Experimental protocols............................................................ 13

2.1.2. Cardiac pacing procedure....................................................... 14

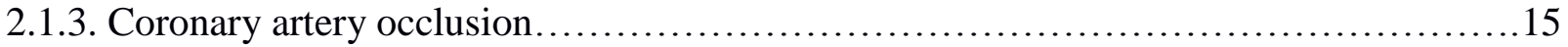

2.1.4 Evaluation of ventricular arrhythmias............................................ 16

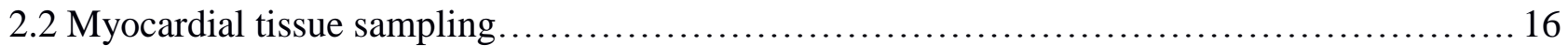

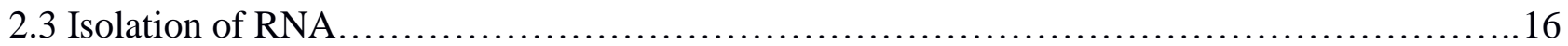

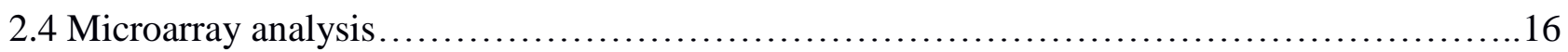

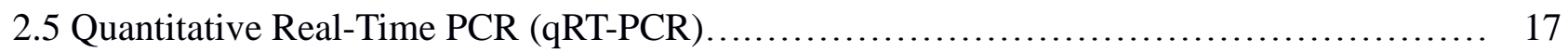

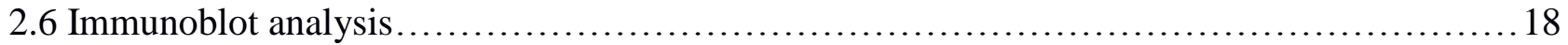

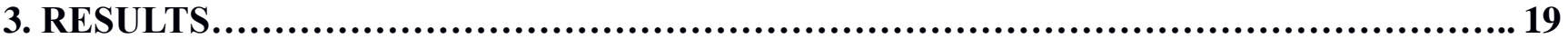

3.1 Gene expression changes following cardiac pacing measured by cDNA microarray............ 19

3.2 Gene expression changes following cardiac pacing determined by qRT-PCR analysis..........21

3.3 Time-course changes in gene expression following cardiac pacing in dogs................... 23

3.4 Time-course changes in eNOS protein content and activation............................ 25

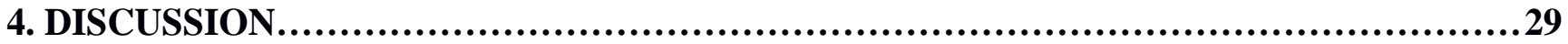

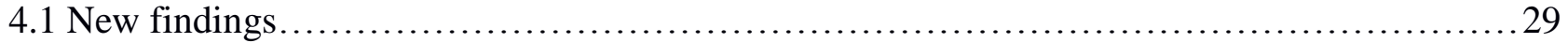

4.2. Changes in transcription levels of different genes after delayed PC by cDNA microarray...... 30

4.3 Effects of rapid cardiac pacing on gene expression changes.................................... 32

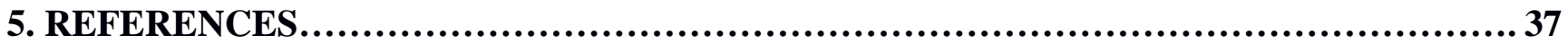

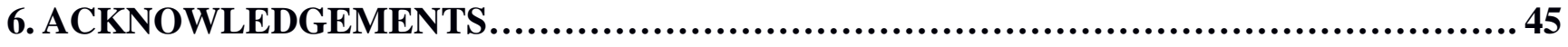

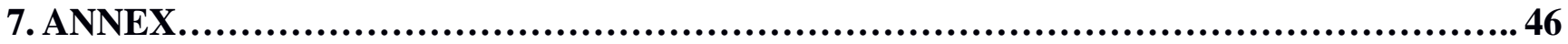




\section{LIST OF ABBREVIATIONS}

\begin{tabular}{|c|c|}
\hline AEST & S-(2-aminoethyl)-isothiourea \\
\hline Akt & also known as Protein kinase B (or PKB) \\
\hline ATF-3 & Activating transcription factor 3 \\
\hline BAD & Bcl-2-associated death promoter \\
\hline Bcl-2 & B-cell lymphoma 2 \\
\hline cDNA & Complementary DNA \\
\hline cGMP & Cyclic guanosine monophosphate \\
\hline $\mathbf{C t}$ & Threshold cycle \\
\hline ECL Kit & Enhanced chemiluminescence kit \\
\hline EDTA & Ethylenediaminetetraacetic acid \\
\hline eNOS & Endothelial nitric oxide synthase \\
\hline iNOS & inducible nitric oxide synthase \\
\hline nNOS & neuronal nitric oxide synthase \\
\hline ERK & Extracellular-signal-regulated kinase \\
\hline GPCR & G protein coupled receptor \\
\hline GSK3 $\beta$ & Glycogen synthase kinase 3 beta \\
\hline HPRT & Hypoxanthine-guanine phosphoribosyltransferase \\
\hline HRP & Horseradish peroxidase \\
\hline HSP22, 27, 28, 70 & Heat shock protein $22,27,28,70$ \\
\hline L-NAME & L-NG-Nitroarginine Methyl Ester \\
\hline LAD & Left anterior descending artery \\
\hline LCX & Left circumflex artery \\
\hline МАРКАРК-3 & Mitogen-activated protein kinase-activated protein kinase-3 \\
\hline mitoK $_{\mathrm{ATP}}$ & Mitochondrial $\mathrm{K}_{\mathrm{ATP}}$ channel \\
\hline mPTP & Mitochondrial permeability transition pore \\
\hline PDE & Phosphodiesterase \\
\hline PC & Preconditioning \\
\hline PI3K/ PI3 kinase & Phosphatidylinositol 3-kinase \\
\hline PKCE & Protein kinase $\mathrm{C}$ epsilon type \\
\hline PKG & cGMP-dependent protein kinase or Protein Kinase G \\
\hline PVDF & Polyvinylidene fluoride \\
\hline qRT-PCR & Quantitative reverse transcription polymerase chain reaction \\
\hline RDA & Representational difference analysis \\
\hline ROS & Reactive oxygen species \\
\hline sGC & Soluble guanylyl cyclase \\
\hline SDS & Sodium dodecyl sulfate \\
\hline Src & also known as tyrosine-protein kinase Src (short for sarcoma) \\
\hline SSC buffer & Saline-sodium citrate buffer \\
\hline TRIS-HCI & Tris(hydroxymethyl)aminomethane hydrochloride \\
\hline VBP & Ventricular premature beats \\
\hline VDAC & Voltage-dependent anion channel \\
\hline VF & Ventricular fibrillation \\
\hline VT & Ventricular tachycardia \\
\hline
\end{tabular}




\section{INTRODUCTION}

One of the most important consequences of acute myocardial ischemia, is the occurrence of the life threatening ventricular arrhythmias, which are responsible in most instances for sudden cardiac death. This is one of the major causes of mortality in the developed countries. Due to several disadvantages of the current antiarrhythmic drug therapy, resulting from a proarrhythmic effect, significant efforts have been made to explore new therapeutic strategies against ventricular arrhythmias. For example preconditioning is one of the endogenous cardioprotective phenomena, which may offer a new tool to attenuate ventricular arrhythmias.

\subsection{The antiarhythmic effect of ischemic preconditioning and rapid cardiac pacing}

The cardioprotective phenomenon, termed ischemic or 'classic' preconditioning was first described by Murry et al. [1] in 1986. They have reported that multiple brief ischemic episodes protect the heart against the severe consequences of a more prolonged ischemic insult, such as ATP loss or myocardial cell death. Since then, it has been established that preconditioning not only reduces infarct size, but markedly attenuates the severity of the ischemia and reperfusioninduced ventricular arrhythmias [2], and enhances the recovery of contractile function following ischemia and reperfusion [3].

Apart from the 'classical' ischemic preconditioning, there are other stimuli which are able to induce cardioprotection. For example, in dogs subjected to two, 2 min periods of cardiac pacing at a rate of 300 beats $\min ^{-1}$, the number and the severity of arrhythmias, such as ventricular tachycardia and ventricular fibrillation, were markedly reduced compared with the unpaced controls [4].

The antiarrhythmic effect of preconditioning appears in two phases. For example, Kaszala et al showed when pacing the hearts four times for $5 \mathrm{~min}$, at a rate 240 beats $\mathrm{min}^{-1}$ there is an early protective phase, which occurs immediately after the stimulus, but it lasts for less than $1 \mathrm{~h}$. The antiarrhythmic protection re-appears spontaneously approximately 20-24h later and, this phase is termed as delayed or 'second window' of protection [5]. Interestingly, if the pacing protocol is repeated at a time when the protection from the previous stimulus has already been lost (i.e. $48 \mathrm{~h}$ after the first pacing), the antiarrhythmic protection persists even for days [6]. 


\subsection{Mechanism of the early protection induced by preconditioning}

Since first described in 1986, the phenomenon of preconditioning stimulated considerable interest to explore the underlying mechanism with the hope of finding a new therapeutic strategy against myocardial ischemic damage and its serious consequences. Despite the extensive research the precise mechanism by which preconditioning induces cardioprotection is still not fully understood.

It is well accepted that endogenous substances generated and released from the myocardium in response to the preconditioning stimulus and play a role in the initiation and mediation of the protection, first published in [7]. These substances, such as adenosine, bradykinin, opioids, prostanoids, nitric oxide and ROS, bind to their receptors or other targets and activate different signal transduction pathways and end-effectors [8].

Studies identified numerous signaling pathways that might have important role in the early phase of the protection. For example, adenosine, bradykinin, prostanoids, opioids that are released by an ischemic stimulus bind to GPCR and activate PI3 kinase. This stimulates numerous downstream pathways, such as the PI3K-Akt-eNOS-NO-sGC-PKG, the PI3K-Akt-ERK, the $\mathrm{PI} 3 \mathrm{~K}-\mathrm{Akt}-\mathrm{GSK} 3 \beta$ or the PI3K-Akt-BAD/caspase9 mediated signaling processes reviewed by [8]. PKC $\varepsilon$ and ERK are also downstream parts of the PI3 cascade [8]. For example, we have demonstrated that the NO-sGC-PKG signaling pathway is important in the induction and mediation of the early protection. The experimental evidence comes from studies in which the inhibition of NO synthesis by L-NAME markedly attenuated the early antiarrhythmic protection [9]. Furthermore, the same result was observed if sGC was inhibited with methylene blue [10].

These PC-induced survival pathways act on numerous end effectors. One of these, for example, is the mitochondria which plays a central role in the ischemia and reperfusion injury. During ischemia but mainly upon reperfusion, the ROS and $\mathrm{Ca}^{2+}$ overload lead to the forming and opening of the MPTP at the mitochondrial level, resulting in the depletion of ATP, irreversible oxidation of proteins, lipids, and DNA within the myocardium, and finally lead to robust mitochondrial swelling, cytochrome c release and later to cell death [11].

The survival signaling, induced by PC, acts directly on the inhibition of mPTP or prevents the conditions which lead to the opening of mPTP. One of the end-effectors for this is the mitoK $\mathrm{ATP}_{\mathrm{ATP}}$ channels, which are involved in regulating mitochondrial matrix volume. Early studies showed that inhibitors of mitoK $\mathrm{ATP}_{\mathrm{ATP}}$ channels blocked [12] and the openers mimicked the protection 
afforded by PC $[13,14]$. The activated mitoK $_{\text {ATP }}$ decreases mitochondrial membrane potential which reduces the $\mathrm{Ca}^{2+}$ uptake during ischemic damage [15]. This activation mechanism is conducted through the NO-mediated signaling and also by PKCe [16, 17]. The activation of mitoK $_{\text {ATP }}$ also results in the release of small levels of ROS which is thought to play a trigger role in $\mathrm{PC}$ by further enhancing the activation of $\mathrm{PKC} \varepsilon$, thereby amplifying the survival signaling [18]. Another target of the survival signaling is to inhibit the formation of mPTP directly [19, 20]. The inhibition of GSK3 $\beta$ through the PI3K pathway reduces the formation of mPTP [21]. Furthermore, PKCe has also been shown to phosphorylate VDAC through which the mPTP formation is blocked [22].

Apoptotic processes have also been implicated in ischemia and reperfusion injury. Apoptosis occurs via the activation of the caspase cascade which was also discovered as one of the targets of the survival pathways [23]. For example, Akt, activated after a PC stimulus, binds and inhibits the proapoptotic members of the Bcl-2 family, such as BAD and casp9 by phosphorylation through which the apoptotic processes are inhibited following the ischemia and reperfusion injury [24]. Another example is ERK, which is activated by PKCe in response to a PC stimulus and phosphorylates therefore inhibits the proapoptotic factor BAD [25].

Apart from the changes in cell viability, the metabolic and electric communication between cardiomyocytes is also damaged during ischemia and reperfusion which is in close relation with the generation of arrhythmias [26]. There is evidence from in vitro experiments that PC preserves gap junction function by preventing the dephosphorylation of the main gap junction forming protein $\mathrm{Cx} 43$ resulting from myocardial ischemia [27]. In response to a PC stimulus, the activated survival kinases such as PKC isoforms ( $\alpha$ and $\varepsilon$ ) as well as PKG phosphorylate Cx43 thereby contributing to the attenuation of the generation of arrhythmias after the coronary artery occlusion [27].

\subsection{Mechanism of the late protection induced by preconditioning}

There is abundant evidence that gene expression changes play an important role in the delayed phase of cardioprotection afforded by preconditioning, reviewed in [28]. The endogenous substances that are released by preconditioning serve as triggers for the development of the early phase trough activation of the survival signaling and acting on various end-effectors. The activation of these pathways decays with time, resulting in the attenuation and then the loss of 
protection. Nevertheless, these pathways also stimulate the transcription of cardioprotective genes that induce the late protection, which occurs approximately 20-24h after the initial PC stimulus [28].

Previous studies have been identified several proteins as possible mediators in the late phase of protection such as the iNOS [6, 29, 30, 31, 32], Cox2 [29], aldose reductase, antioxidant enzymes, particularly MnSOD, [33], and heat stress proteins. Among the various cellular kinases that are activated by various PC stimuli, PKC [34] and Src protein tyrosine kinases play an essential role in the development of late PC [35].

It has now become clear, that the late protection is a complex phenotype involving multiple genes and can be considered as a whole genomic response initiated by various preconditioning stimuli. With the different tools of genomics which aims to study changes in gene expression, attention has turned to the exploration of the mechanism behind such multigenic phenomenon. Using large scale gene profiling techniques such as cDNA microarrays differential display or subtractive hybridization techniques, it was found that ischemic changes activate a protective genetic program which enables cardiomyocytes to overcome the harmful consequences of an otherwise lethal ischemic insult. Depre et al showed [36] in a pig ischemia model that genes from different cell survival pathways, including anti-apoptotic (i.e. the serine protease inhibitors plasminogen activator 1 and 2), cytoprotective genes (e.g. heat shock proteins) as well as cell growth promoters were up-regulated using gene microarray technique. Furthermore, Simkhovich et al. $[37,38]$ has found that protective genetic program was activated in rabbit and rat hearts following a brief episode of ischemia. They have found that transcripts, encoding the cytoprotective MAPKAPK-3, HSP 22, 27, 28, 70 iNOS and alpha B-crystalline, cell growth promoters (ATF-3 and H11 kinase) were increased. Ónodi et al has identified numerous genes with different functions following preconditioning using cDNA microarray with 3200 rat specific genes [39]. These genes were involved in protein degradation, stress response (heat shock proteins), apoptosis, metabolic processes and various regulatory mechanisms.

These studies have demonstrated that preconditioning mediated by short durations of reversible ischemia could result in the reprogramming the expression pattern of gene with diverse functions. For example, genes involved in stress response, such as antioxidants and heat shock proteins, were the most common genes which showed an altered transcription pattern in response to IPC [40]. Furthermore, genes encoding mitochondrial proteins and members of the survival signaling 
or anti-apoptotic factors are also dramatically altered after IPC [40]. In our recent study, we have shown that cardiac pacing results in time-dependent changes in $\mathrm{Cx} 43$ gene and protein expression, which may alter gap junction function and influence arrhythmia generation during a subsequent ischemia and reperfusion insult [41].

There is no doubt that gene expression changes are important for the development of the late protection induced by short ischemic periods, but the transcriptional alterations in the antiarrhythmic adaptation induced by rapid cardiac pacing are less understood.

\subsection{Mechanisms involved in the delayed antiarrhythmic protection induced by rapid cardiac pacing}

The experimental evidence that bradykinin has an important role in the antiarrhythmic effect of cardiac pacing comes from previous results in anesthetized dogs. These demonstrated that incatibant (HOE 140), an antagonist of bradykinin at B2 receptors, attenuates the pacing-induced early and delayed antiarrhythmic protection [42, 43]. In the presence of incatibant, pacing the heart through the right ventricle increased the severity of arrhythmias and ischemia during the pacing protocol, and abolished the antiarrhythmic protection during coronary artery occlusion and reperfusion [42].

The first evidence that NO is a key mediator not only in the early but also in the late protection came from studies in which the non-selective iNOS inhibitor, dexamethasone abolished the delayed antiarrhythmic protection resulted from rapid cardiac pacing [29]. Later this had been confirmed by studies using more selective inhibitors of iNOS [6, 30, 31, 44]. For example, when aminoguanidine [31] and AEST [6] was administered prior to the occlusion in dogs that were subjected to cardiac pacing $24 \mathrm{~h}$ previously, the antiarrhythmic protection was abolished. Similarly, the repeated cardiac pacing-induced prolonged protection [6] as well as the heavy physical exercise-induced delayed antiarrhythmic effect [44] were both sensitive for selective (AEST) and non-selective (L-NAME) inhibitors of iNOS, indicating a role for iNOS activation in the development of the delayed cardioprotection.

Since these inhibitors are not entirely selective for iNOS, for example dexamethasone inhibits cox-2 as well [29], whereas L-NAME interferes NO formation resulting from activation of any NOS enzymes [44], the role for other isoforms of NO producing enzymes in the delayed phase of the protection can not be ruled out. 
Using in vitro methods, other studies have reported that the activity of constitutive calciumdependent NOS enzymes (eNOS and nNOS) was increased only immediately after preconditioning, but remained unaffected 24h later [45], whereas the mRNA of iNOS was upregulated and showed marked enzymatic activation only during the late phase of the protection [32]. They have put forth a hypothesis that NO is generated from the activation of constitutive NOS enzymes and induces the transcription of iNOS thereby enhances further NO generation at later time points (NO induced NO formation). Since in our previous studies we had only pharmacological evidence for the role of NO in the delayed antiarrhythmic protection we have now aimed to investigate this by using molecular biology approach.

\subsection{Aims of the study}

The objectives of the present studies were to explore the mechanism of the antiarrhythmic protection induced by rapid cardiac pacing by gene expression profiling. Therefore,

I. In Study I, we have attempted to examine gene expression changes following ischemia and reperfusion in dogs subjected to rapid right ventricular pacing twenty-four hours previously. Two approaches were used:

- cDNA microarray analysis which enables to identify the transcription patterns of genes activated by a certain intervention such as cardiac pacing, and

- qRT-PCR by which we analyzed the transcription of 45 selected genes, which had already been proposed to play roles in the delayed phase of the preconditioning-induced protection.

II. In Study II, the time course changes of gene expression following rapid cardiac pacing have been analyzed.

\section{MATERIALS AND METHODS}

\subsection{Experimental protocols and surgical interventions}

Adult mongrel dogs of both sexes were used (mean body weight $20 \pm 1 \mathrm{~kg}$ ) in these studies. The origin and upkeep of these dogs were in accordance with the Hungarian law (XXVIII, chapter IV, paragraph 31) regarding large experimental animals, which conforms with the Guide for the Care 
and Use of Laboratory Animals published by the US National Institute of Health (NIH Publication No. 85-23, revised 1996).

\subsubsection{Experimental protocols}

In Study I and II, a total of thirty-three dogs were instrumented by introducing a pacing electrode into the right ventricle (Figure 1).

In Study I, three dogs served as sham paced and sham operated controls (C). In these animals, the pacing electrode was introduced into the right ventricle, but the dogs were not paced. Twentyfour hours later these dogs were re-anesthetized, thoracotomised and instrumented but were not subjected to coronary artery occlusion. Another three sham-paced dogs, 24h after the instrumentation, were subjected to a 25 min occlusion of the left anterior descending (LAD) coronary artery. These animals served as the ischemic controls (IC). Other three dogs were paced on day one and 24h later were subjected to a 25 min LAD occlusion (PO group). After euthanasia with an intravenous overdose of the anesthetic the hearts were sectioned at the time points indicated by arrows (Figure 1) and tissue samples were taken for further biochemical analysis. In Study II, twelve animals were subjected to rapid cardiac pacing $(\mathrm{P})$, whereas another twelve dogs served as sham-paced controls (SP). Dogs of the paced and non-paced groups were divided into 4 further groups, each containing 3 animals. From these dogs after euthanasia with an intravenous overdose of the anesthetic the hearts were excised immediately (P-0h/SP-0h), six (P-6h/SP-6h), twelve (P-12h/SP-12h) or twenty-four (P-24h/SP-24h) hours after the pacing or sham-pacing procedures (Figure 1). 


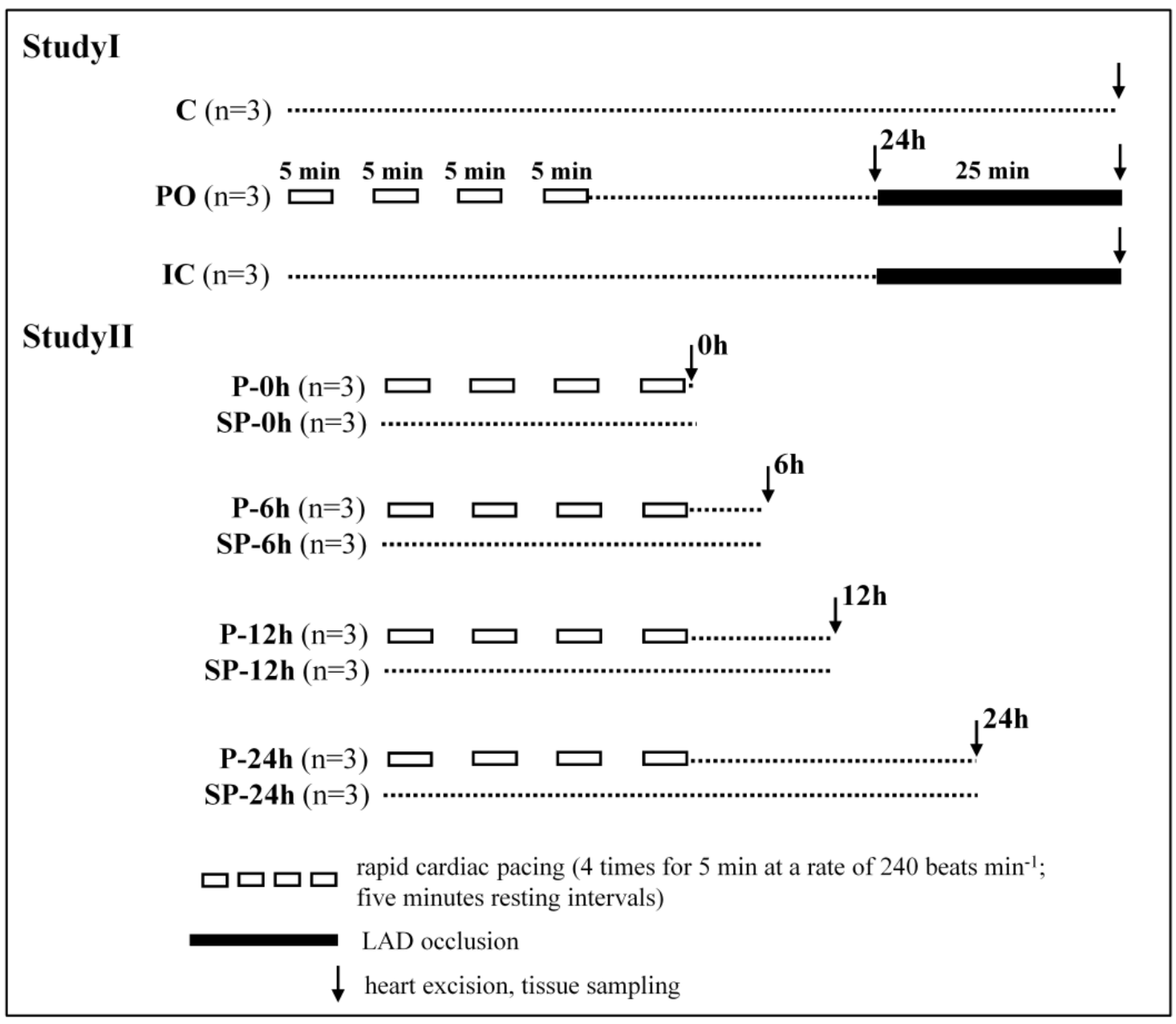

Figure 1. Experimental protocols. In Study I, relative gene expression changes were determined in three groups of dogs; controls were sham paced and sham operated dogs, without (C) and with ischemia (IC) and in paced dogs that were subjected to coronary artery occlusion and reperfusion, 24h after pacing (PO). In Study II, the time-course changes in gene expression occurring after rapid cardiac pacing were determined at four time points both in the unpaced and paced dogs (P0h, P-6h, P-12h, P-24h).

\subsubsection{Cardiac pacing procedure}

The pacing procedure was performed as described previously [5]. In brief, the dogs were lightly anesthetized by the intravenous administration of sodium pentobarbitone $\left(0.5 \mathrm{mg} \mathrm{kg}^{-1}\right.$ i.v., Euthanyl ${ }^{\circledR}$ Bimeda-MTC Animal Health Inc.) and were allowed to breathe spontaneously. Arterial blood pressure was monitored from the left carotid artery using methods previously described in 
detail (Kaszala et al 1996, Vegh et al 1992). Through the right jugular vein, a pacing electrode (CordisF4, Johnson \& Johnson Company, USA) was inserted into the right ventricle such as that it made contact with the ventricular wall. The correct placing of the electrode was confirmed by recording the endocardial electrocardiogram. The dogs were then paced at a rate of 240 beats $\min ^{-1}$ for four $5 \mathrm{~min}$ periods with $5 \mathrm{~min}$ rest intervals between the pacing stimuli. The shampaced controls were those in which the pacing electrode was positioned into the right ventricle, as described above but the dogs were not paced. The effect of pacing was followed by measuring changes in subendocardial ST-segment elevation immediately after cessation of pacing using the pacing electrode.

\subsubsection{Coronary artery occlusion}

Twenty-four hours later, those dogs that had been selected for coronary artery occlusion (in the IC and PO groups) were re-anesthetized with a mixture of $\alpha$-chloralose and urethane (60 and 200 $\mathrm{mg} \mathrm{kg}{ }^{-1}$, respectively Sigma, USA), intubated and ventilated with room air using a Harvard respirator (Harvard Apparatus, USA) at a rate and volume sufficient to maintain arterial blood gases and $\mathrm{pH}$ within the normal limits [2]. Body temperature was measured from the midesophagus, and maintained at $37 \pm 0.5^{\circ} \mathrm{C}$ by means of a heating pad. Polyethylene catheters were inserted into the right femoral vein and into the femoral artery for further administration of the anesthetic and to measure arterial blood pressure. The catheter inserted in the left carotid artery previously was then led to the left ventricle to measure changes in left ventricular pressure and $\mathrm{dP} / \mathrm{dt}$.

A thoracotomy was performed at the fifth intercostal space and the anterior descending branch of the LAD was prepared for occlusion just proximal to the first main diagonal branch. Myocardial ischemia was induced by a 25 min occlusion of this artery as described previously (Vegh et al 1992). The severity of myocardial ischemia was assessed by the measurement of changes in the degree of inhomogeneity of electrical activation and in epicardial ST-segment by means of a composite electrode described previously [2]. The depth of anesthesia was monitored by the examination of the cornea and pain reflexes as well as by the measurement of blood pressure, and when it was necessary a further bolus injection of the anesthetic was given. 


\subsubsection{Evaluation of ventricular arrhythmias}

Ventricular arrhythmias were assessed according to the Lambeth Conventions [46] with that modification as has been previously outlined [2]. In brief, the total number of VBPs, the incidence and number of episodes of ventricular tachycardia (defined as a run of four or more VBPs at a rate faster than the resting heart rate), and the incidence of VF were assessed during the occlusion period.

\subsection{Myocardial tissue sampling}

At the end of the experimental protocols the animals were given an overdose of the anesthetic, and the hearts were rapidly excised and placed in ice cold saline. Tissue samples were taken from the ischemic area (supplied by the LAD) and from the non-ischemic area (supplied by the LCX) for further analysis.

\subsection{Isolation of RNA}

Tissue samples from both the ischemic and non-ischemic myocardial regions were powdered in liquid nitrogen and $25 \mathrm{mg}$ was used for RNA isolation. Then total RNA was purified with the RNeasy Fibrous Tissue Mini Kit (Qiagen, Germany) according to the manufacturer's instruction. The integrity of RNA was assessed by gel electrophoresis and the concentration of total RNA was determined by UV-photometry. DNaseI digestion was also performed to avoid the potential genomic DNA contamination. The RNA preparations from 3 dogs in each group were pooled together. The total RNA preparations were used for microarray analysis and qRT-PCR measurements.

\subsection{Microarray analysis}

The microarray analysis was performed as described by [47]. In brief, human cDNA microarray containing 3200 human cDNA clones was used for the hybridization. For probe preparation, $2 \mu \mathrm{g}$ of total RNA was reverse transcribed using poly-dT-primed Genisphere Expression Array 350 Detection Kit system (Genisphere, USA) according to the manufacturer's instructions. Both cDNA hybridization and capture reagent hybridization were carried out in a Ventana

hybridization station (Ventana discovery, USA) using the "antibody" protocol. The first hybridization was performed at $40{ }^{\circ} \mathrm{C}$ for 6 hours in "FGL2" hybridization buffer (10xDenhart 
solution, 0.25 M sodium phosphate buffer $\mathrm{pH}$ 7.0, 1mM EDTA, 1x SSC, 0.5\% SDS), then $2.5 \mu 1$ each of Cy5 and Cy3 capture reagents in $200 \mu 1$ "Chiphyb" hybridization buffer (Ventana) were added to the slides and incubated at $42{ }^{0} \mathrm{C}$ for 2 hours. After hybridization, the slides were washed twice in 0.2 X SSC at RT for 10min, then dried and scanned.

Each array was scanned under a green laser (532 nm) (for Cy3 labeling) and under a red laser (660 nm) (for Cy5 labeling) using a ScanArray Lite (GSI Lumonics, Billerica, MA, USA) confocal fluorescent scanner with $10 \mu \mathrm{m}$ resolution. Image analysis was performed by ScanAlyze2 software (http://www.microarrays.org/software.html). Each spot was defined by manual positioning of a grid of circles over the image. The average pixel intensity and the local background of each spot were determined. To measure the 'expression ratio', MRAT (denotes the median of the set of background-corrected single pixel intensity ratios of the two channels within the spot) was determined. This average expression ratio for all genes on the array was normalized to 1.0. For background corrections those data were calculated as negatives where the average intensity of the spot was smaller than two times the average background of the same area. Significant spots have more than 0.55 CHGTB2 values (denotes fraction of pixels in the spot greater than background) in both $\mathrm{Cy} 3$ and $\mathrm{Cy} 5$ channels. To reduce the number of false positive or false negative ratios, two probes were generated from each RNA pool: a Cy5-labeled and a Cy3-labeled one in order to perform replicate experiments. Replica spots (on the same array) and replica experiments (two different arrays) resulted in four data points for every gene. Those spots were excluded from further analysis when ratios of the replica spots had a more than two-fold difference. The same restriction was applied for the average ratios of the replica experiments.

\subsection{Quantitative Real-Time PCR (qRT-PCR)}

Quantitative RT-PCR was performed by ABI7000 instrument (Applied Biosystems, Carlsbad, USA) with gene-specific primers to monitor gene expression changes. Two $\mu \mathrm{g}$ of total RNA from each sample was reverse transcribed using ImPromII reverse transcriptase (Promega, USA) in the presence of poly $(\mathrm{dT})$ primers at $42{ }^{\circ} \mathrm{C}$ for $1 \mathrm{~h}$. After this, cDNAs were diluted in $50 \mu \mathrm{l}$ water, and $1 \mu \mathrm{l}$ of this reaction mix was used as template for qRT-PCR. This was performed using the SYBRGreen protocol with SYBR Green PCR Master Mix with passive reference dye (Applied Biosystems, Carlsbad, USA) according to the manufacturer's instructions at a final primer concentration of $500 \mathrm{nM}$. The primers were designed using the PrimerExpress 2.0 (Applied 
Biosystems, Carlsbad, USA) and verified by NCBI-BLAST. Relative expression ratios were calculated as normalized ratios to HPRT and to tubulin. A non-template control sample was applied for each run to control the genomic DNA contaminations of the template. Melting temperature analysis has been performed after each reaction to assess the quality of the reaction. The final relative gene expression changes were calculated as delta-delta $\mathrm{Ct}$ values. Genes with expression values lower than 0.5 or higher than 1.5 were considered to be down or up-regulated (the values correspond to an interval of $\log 2=-1$ and $\log 2=0.6$ ). All the PCRs were performed in triplicate with two parallel runs for each reaction. All data were expressed as mean \pm SD.

\subsection{Immunoblot analysis}

Transmural tissue samples from both the ischemic and non-ischemic regions of the left ventricle were powdered in liquid nitrogen and stored at $-80^{\circ} \mathrm{C}$. The samples were then homogenized in ice cold lysis buffer $(20 \mathrm{mM}$ Tris- $\mathrm{HCl} \mathrm{pH} \mathrm{7.4,} 250 \mathrm{mM}$ sucrose, $0.1 \%$ protease inhibitor cocktail, Sigma) and centrifuged at $2000 \mathrm{~g}$ for $15 \mathrm{~min}$. The supernatant was used either as a total protein fraction or centrifuged at $50000 \mathrm{~g}$ for $45 \mathrm{~min}$ and the pellet was re-suspended in ice cold lysis buffer and used as the membrane fraction. Protein concentrations were determined by the method of Lowry. Total protein samples of 100ug and membrane protein extracts of 80ug were separated on $8 \%$ polyacrylamide gels and transferred to PVDF membranes (Millipore). After blocking in $5 \%$ non-fat milk (for one hour at room temperature), the membranes were incubated with two different primary antibodies. Anti-eNOS (BD Transduction Laboratories ${ }^{\mathrm{TM}}$ ) was used to measure the protein expression of eNOS (in a dilution of 1:3000) and anti-phospho-eNOS (peNOS, Ser1177, BD Transduction Laboratories ${ }^{\mathrm{TM}}$ ) to detect the activation of eNOS (in a dilution of 1:1000) by the Akt/PI3 kinase pathway. This was followed by one hour incubation of HRPconjugated goat anti-rabbit secondary antibody at room temperature (in a dilution of 1:8000). Blots were developed with ECL plus kit (GE Healthcare) and exposed to X-ray films (Amersham Biosciences). Band densities were measured using ImageJ software (NIH). For the precise comparison of the three parallel western blots, each pixel intensity was normalized to the highest value on each blot. For verification of equal loading, Coomassie staining was performed. Values are mean \pm S.E.M. $*$ P $<0.05$ vs. SP group (Bonferroni correction). 


\section{RESULTS}

\subsection{Gene expression changes in control and paced dogs subjected to coronary artery occlusion and reperfusion twenty-four hours later}

cDNA microarray analysis was performed in order to identify gene expression changes in the pacing-induced delayed antiarrhythmic protection. The expression values of the ischemic and preconditioned groups were compared to those obtained from the sham paced, sham operated control dogs. Their relative expression ratios are shown in Table 1. The data obtained from cDNA microarrays were confirmed by qRT-PCR analysis.

Out of the studied 3200 cDNAs four genes were down- and five genes were up-regulated in the ischemic group compared to the control dogs. Compared to the IC group, cardiac pacing resulted in an enhanced expression of 19 genes and lower expression of 4 genes. These genes with altered transcription rate encode transcription factors, ion channels and members of signal transduction pathways. Some of these, for example MEF2A and PDE4D9 were not significantly changed in response to myocardial ischemia, but were up-regulated following rapid cardiac pacing. In contrast, three genes (14-3-3zeta, AVPR1, AVPR2), that showed higher expression in the ischemic controls, were either not changed (14-3-3zeta) or down-regulated (AVPR1, AVPR2) in dogs paced $24 \mathrm{~h}$ previously. The abbreviations of this section can be found in the Table 1 . 


\begin{tabular}{|c|c|c|c|c|}
\hline Categories & Gene name & Accession & $\mathrm{IC} / \mathrm{C}$ & PO/IC \\
\hline \multirow[t]{3}{*}{ ion channel/transcription factors } & chloride intracellular channel protein 1 (NCC27) & XM_532079 & 0.37 & 2.36 \\
\hline & rearranged L-myc fusion (ZN-15 related zinc finger protein) & XM_532543 & 1.17 & 0.54 \\
\hline & myocyte enhancer-binding factor 2 (MEF2) & XM_536298 & 1.14 & 4.28 \\
\hline metabolic enzyme & alcohol dehydrogenase 1C, gamma polypeptide (ADH1C) & XM_535667 & 0.65 & 3.83 \\
\hline \multirow[t]{10}{*}{ signal transduction } & prolactin receptor (PRLR) & XM_536502 & 1.20 & 1.88 \\
\hline & arginine vasopressin receptor 1 (VR1) & XM_538263 & 2.16 & 0.43 \\
\hline & arginine vasopressin receptor 2 (VR2) & NM_001003177 & 2.12 & 0.45 \\
\hline & protein tyrosine phosphatase, receptor type, J precursor (PTPRJ) & XM_540737 & 0.52 & 0.38 \\
\hline & tumor necrosis factor receptor member 10A precursor (TRAIL-R1) & XM_543245 & 2.84 & 1.45 \\
\hline & interleukin-1 receptor-associated kinase 1 (IRAK-1) & XM_549367 & 0.54 & 2.69 \\
\hline & $\begin{array}{l}\text { tyrosine 3-monooxygenase/tryptophan 5-monooxygenase activation protein, } \\
\text { zeta polypeptide (14-3-3 zeta) }\end{array}$ & XM_533072 & 1.89 & 0.53 \\
\hline & cAMP-specific phosphodiesterase variant (PDE4D9) & XM_535243 & 0.65 & 3.83 \\
\hline & transforming growth factor, beta 2 (TGFB2) & XM_545713 & 0.97 & 1.88 \\
\hline & phosphorylase b kinase gamma catalytic chain, skeletal muscle isoform (PHKG1) & XM_546902 & 0.53 & 2.24 \\
\hline \multirow[t]{12}{*}{ others } & ST3 beta-galactoside alpha-2,3-sialyltransferase 1 (ST3GAL1) & XM_539171 & 1.40 & 1.85 \\
\hline & DEAD/H (Asp-Glu-Ala-Asp/His) box polypeptide 11 & XM_543872 & 0.83 & 0.50 \\
\hline & granzyme K precursor & XM 546318 & 1.07 & 1.88 \\
\hline & zinc finger protein, $\mathrm{X}$-linked (ZFX) & AF027765 & 1.01 & 1.91 \\
\hline & translocation associated membrane protein 1 (TRAM1) & NM_001003267 & 0.43 & 2.02 \\
\hline & phosphatidylinositol glycan, class Q isoform 2 & XM_547216 & 0.30 & 3.34 \\
\hline & A-kinase anchor protein 6 (mAKAP) & XM_547766 & 0.81 & 2.28 \\
\hline & midline 1 isoform alpha & XM_548857 & 0.36 & 4.10 \\
\hline & necdin & XM_545810 & 0.45 & 2.49 \\
\hline & gastric inhibitory polypeptide receptor precursor (GIPR) & XM_541554 & 1.61 & 1.80 \\
\hline & WD-repeat protein 26 (WDR26) & XM_537237 & 1.05 & 1.88 \\
\hline & GPATCH8 G patch domain containing 8 (GPATCH8) & XM_537619 & 0.72 & 1.93 \\
\hline
\end{tabular}

Table 1. Gene expression changes following cardiac pacing by cDNA microarray. The expression values were calculated from the intensity ratios obtained from the scanning analysis of the cDNA microarray as described in the section of Materials and Methods. (The values labeled with red indicate up-regulation while the data labeled with blue indicate down-regulation). Each experiment was performed twice. 


\subsection{Gene expression changes following cardiac pacing determined by $q R T-P C R$ analysis}

QRT-PCR was performed to study 45 genes which have previously been identified as potential mediators or important members of the preconditioning-induced cardioprotection. Thus, genes encoding gap junction proteins ( $\mathrm{Cx} 40 ; \mathrm{Cx} 43$; $\mathrm{Cx} 45)$ NO producing enzymes (iNOS, eNOS, nNOS), cyclooxygenases (COX1, COX2), antioxidants (CAT, Mn-SOD, Cu/Zn-SOD), antiapoptotic and apoptotic proteins (BAX, BAK, Casp3, Casp9), heat shock proteins (HSP27, HSPA8), cytokines (IL-6, TNF $\alpha$ ); growth factors (TGF $\beta$, TGFBR2), transcription factors (c-fos), members of different signal transduction pathways, such as different isoforms of the protein kinase C (PKC $\alpha$; $\mathrm{PKC} \delta, \mathrm{PKC} \varepsilon)$, of the JNKs (JNK1,2,3) and of the sGCs (sGC $\alpha 1 / \beta 1, \mathrm{sGC} \alpha 2 / \beta 2)$ were examined (Table 2).

Out of the 45 studied genes, six exhibited significant down-regulation and 16 showed upregulation in response to myocardial ischemia when compared to the control dogs. Their expression ratios changed either to the opposite (11) or showed no alteration (10) in the PO group (Table 2). Among these nNOS, HSP70, PKC $\alpha$, JNK1, GSK3 $\alpha$, GYS1, BDKRB1 showed upregulation, and $\mathrm{BAX}, \mathrm{BAK}$ and casp3 down-regulation after rapid cardiac pacing.

Figure 2, 3 and 4 illustrate some of these genes from different functional categories, which showed expression changes in response to ischemia and/or preconditioning. The abbreviations of this section are listed in the Table 2 . 


\begin{tabular}{|c|c|c|c|c|}
\hline Categories & Gene name & Accession & $\mathrm{IC} / \mathrm{C}$ & PO/IC \\
\hline gap junction & $\begin{array}{l}\text { gap junction protein, alpha } 5,40 \mathrm{kDa} \\
\text { gap junction protein connexin } 43(\mathrm{Cx} 43) \\
\text { gap junction protein, alpha } 7,45 \mathrm{kDa}\end{array}$ & $\begin{array}{l}\text { NM_005266 } \\
\text { AY462223 } \\
\text { NM_005497 }\end{array}$ & $\begin{array}{l}\mathbf{0 . 2 9}(\mathbf{0 . 0 6}) \\
1.08(0.08) \\
1.10(0.41)\end{array}$ & $\begin{array}{l}1.17(0.21) \\
0.83(0.11) \\
3.64(2.79)\end{array}$ \\
\hline NO production & $\begin{array}{l}\text { endothelial nitric oxide synthase (eNOS) } \\
\text { inducible nitric oxide synthase (iNOS) } \\
\text { neuronal nitric oxide synthase (nNOS) }\end{array}$ & $\begin{array}{l}\text { AF400594 } \\
\text { NM_001003186 } \\
\text { HSU17327 }\end{array}$ & $\begin{array}{l}2.34(\mathbf{0 . 6 8}) \\
\mathbf{1 . 7 9}(\mathbf{0 . 2 3}) \\
0.80(0.07)\end{array}$ & $\begin{array}{l}0.62(0.05) \\
0.58(0.03) \\
\mathbf{2 . 1 6}(\mathbf{0 . 4 6 )}\end{array}$ \\
\hline antioxidants & $\begin{array}{l}\text { catalase }(\mathrm{CAT}) \\
\mathrm{Cu} / \mathrm{Zn} \text { superoxide dismutase }(\mathrm{Cu} / \mathrm{Zn}-\mathrm{SOD}) \\
\mathrm{Mn} \text { superoxide dismutase }(\mathrm{Mn}-\mathrm{SOD}) \\
\text { cytochrome } \mathrm{C} \text { oxydase }\end{array}$ & $\begin{array}{l}\text { NM_001002984 } \\
\text { AF346417 } \\
\text { Y00985 } \\
\text { T19137 }\end{array}$ & $\begin{array}{l}1.06(0.08) \\
0.83(0.09) \\
2.80(\mathbf{1 . 7 1 )} \\
\mathbf{1 . 5 4}(\mathbf{0 . 1 1})\end{array}$ & $\begin{array}{l}\mathbf{0 . 2 9}(\mathbf{0 . 1 2}) \\
0.70(0.07) \\
1.08(0.50) \\
\mathbf{0 . 3 5}(\mathbf{0 . 0 8})\end{array}$ \\
\hline miscellaneous & $\begin{array}{l}\text { cyclooxygenase- } 1 \text { (COX1) } \\
\text { cyclooxygenase- } 2(\mathrm{COX} 2) \\
\text { matrix metalloproteinase } 2(\mathrm{MMP} 2)\end{array}$ & $\begin{array}{l}\text { NM_000962 } \\
\text { NM_001003354 } \\
\text { BC002576 }\end{array}$ & $\begin{array}{l}1.02(0.16) \\
1.04(0.41) \\
\mathbf{0 . 3 0}(\mathbf{0 . 1 1})\end{array}$ & $\begin{array}{l}0.95(0.12) \\
1.23(0.43) \\
\mathbf{1 . 9 6}(\mathbf{0 . 1 9 )}\end{array}$ \\
\hline apoptotic genes & $\begin{array}{l}\text { BCL2-associated X protein (BAX) } \\
\text { Bcl-2 antagonist/killer protein (BAK) } \\
\text { caspase } 3 \text { apoptosis-related cysteine } \\
\text { peptidase (CASP3) } \\
\text { caspase } 9 \text { apoptosis-related cysteine } \\
\text { peptidase (CASP9) }\end{array}$ & $\begin{array}{l}\text { NM_001003011 } \\
\text { DQ002813 } \\
\text { NM_001003042 } \\
\text { DQ116956 }\end{array}$ & $\begin{array}{l}1.85(\mathbf{0 . 1 7}) \\
1.50(0.02) \\
2.23(\mathbf{0 . 5 0}) \\
\mathbf{2 . 5 1}(\mathbf{0 . 3 6})\end{array}$ & $\begin{array}{l}\mathbf{0 . 2 8}(\mathbf{0 . 0 6}) \\
\mathbf{0 . 2 4}(\mathbf{0 . 0 4}) \\
\mathbf{0 . 3 7}(\mathbf{0 . 0 9}) \\
0.98(0.07)\end{array}$ \\
\hline heat shock proteins & $\begin{array}{l}\text { heat shock } 27 \mathrm{kDa} \text { protein } 1 \text { (HSP27) } \\
\text { heat shock } 70 \mathrm{kDa} \text { protein } 8 \text { (HSP70) } \\
\text { heat shock } 70 \mathrm{kDa} \text { protein } 1 \mathrm{~A} \text { (HSPA1A) }\end{array}$ & $\begin{array}{l}\text { NM_001540 } \\
\text { NM_006597 } \\
\text { NM_005345 }\end{array}$ & $\begin{array}{l}1.88(0.05) \\
1.82(0.18) \\
2.68(0.56)\end{array}$ & $\begin{array}{l}\mathbf{0 . 4 5}(\mathbf{0 . 0 5}) \\
\mathbf{2 . 7 7}(\mathbf{0 . 6 5 )} \\
0.56(0.09)\end{array}$ \\
\hline cytokines & $\begin{array}{l}\text { tumor necrosis factor alpha (TNF } \alpha) \\
\text { interleukin-6 (IL-6) }\end{array}$ & $\begin{array}{l}\text { NM_001003244 } \\
\text { U12234 }\end{array}$ & $\begin{array}{l}0.60(0.08) \\
\mathbf{0 . 4 9}(\mathbf{0 . 0 4})\end{array}$ & $\begin{array}{l}0.46(0.04) \\
4.09(0.94)\end{array}$ \\
\hline growth factors & $\begin{array}{l}\text { transforming growth factor beta } 1 \text { (TGF } \beta 1 \text { ) } \\
\text { transforming growth factor, beta receptor II }\end{array}$ & $\begin{array}{l}\text { NM_000660 } \\
\text { NM_003242 }\end{array}$ & $\begin{array}{l}3.43(\mathbf{0 . 9 8}) \\
0.89(0.16)\end{array}$ & $\begin{array}{l}\mathbf{0 . 2 0}(\mathbf{0 . 0 2}) \\
0.50(0.02)\end{array}$ \\
\hline transcription & $\begin{array}{l}\text { nuclear factor of kappa light polypeptide } \\
\text { cellular oncogene c-fos }\end{array}$ & $\begin{array}{l}\text { NM_003998 } \\
\text { V01512 }\end{array}$ & $\begin{array}{l}1.11(0.22) \\
\mathbf{0 . 3 0}(\mathbf{0 . 1 1})\end{array}$ & $\begin{array}{l}1.14(0.30) \\
1.45(0.24)\end{array}$ \\
\hline signal transduction & 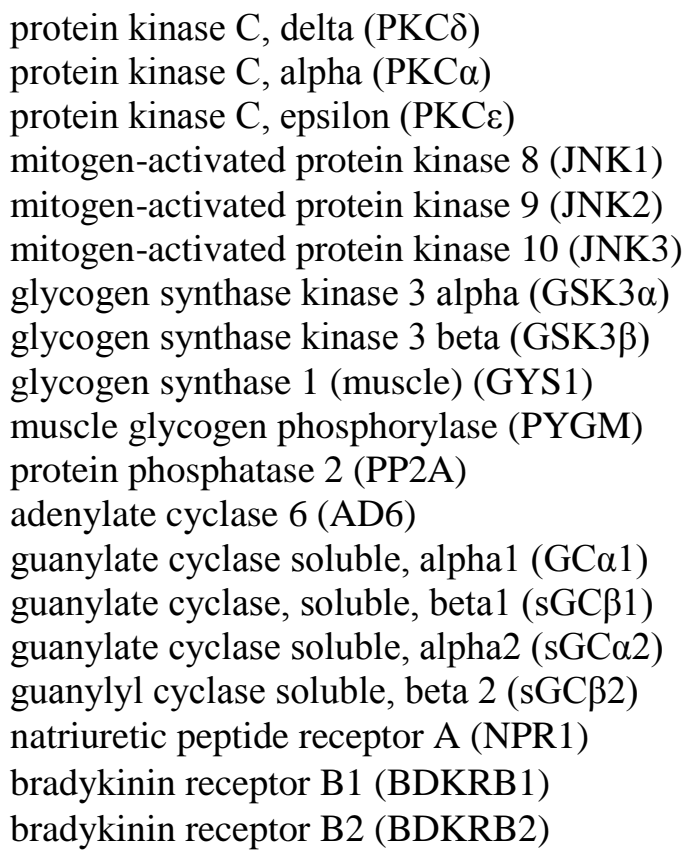 & $\begin{array}{l}\text { NM_001008716 } \\
\text { NM_002737 } \\
\text { NM_005400 } \\
\text { NM_139049 } \\
\text { NM_139070 } \\
\text { BC035057 } \\
\text { BC027984 } \\
\text { BC000251 } \\
\text { NM_002103 } \\
\text { AF066859 } \\
\text { BC032954 } \\
\text { BC064923 } \\
\text { NM_000856 } \\
\text { NM_000857 } \\
\text { NM_000855 } \\
\text { AF038499 } \\
\text { NM_000906 } \\
\text { NM_000710 } \\
\text { AY275465 }\end{array}$ & $\begin{array}{l}2.65(0.55) \\
0.95(0.15) \\
\mathbf{1 . 6 6}(\mathbf{0 . 2 0}) \\
0.83(0.10) \\
0.76(0.10) \\
1.26(0.37) \\
\mathbf{0 . 4 5}(\mathbf{0 . 0 8 )} \\
\mathbf{1 0 . 1 4}(\mathbf{1 . 0 3}) \\
\mathbf{2 . 0 7}(\mathbf{0 . 1 3}) \\
1.30(0.29) \\
1.04(0.08) \\
1.29(0.16) \\
1.38(0.33) \\
0.98(0.11) \\
\mathbf{2 . 3 6}(\mathbf{0 . 2 7}) \\
1.19(0.19) \\
1.20(0.11) \\
\mathbf{0 . 4 3}(\mathbf{0 . 0 8}) \\
\mathbf{9 . 0 8}(\mathbf{9 . 3 6 )}\end{array}$ & $\begin{array}{l}\mathbf{0 . 3 7}(\mathbf{0 . 0 7}) \\
2.57(\mathbf{0 . 6 1}) \\
0.53(0.07) \\
3.31(\mathbf{0 . 0 7}) \\
0.93(0.03) \\
1.19(0.39) \\
\mathbf{1 . 9 4}(\mathbf{0 . 3 2}) \\
0.73(0.06) \\
\mathbf{3 . 3 5}(\mathbf{1 . 0 9 )} \\
1.14(0.15) \\
0.54(0.05) \\
0.80(0.11) \\
1.03(0.21) \\
0.57(0.02) \\
\mathbf{0 . 3 5}(\mathbf{0 . 0 7}) \\
0.50(0.07) \\
0.79(0.09) \\
4.91(\mathbf{2 . 8 0}) \\
\mathbf{0 . 2 5}(\mathbf{0 . 1 2})\end{array}$ \\
\hline
\end{tabular}


Table 2. Gene activity changes $24 \mathrm{~h}$ after cardiac pacing in dogs subjected to coronary artery occlusion and reperfusion. The 45 genes examined were divided into different groups according to the function of proteins they encode. Genes with expression values lower than 0.5 or higher than 1.5 were considered to be down or up-regulated. Values are means \pm SD (indicated in brackets) of three parallel qRT-PCR reactions. (Values labeled with red indicate up-regulation while the data labeled with blue indicate down-regulation).

\subsection{Time-course changes in gene expression following cardiac pacing in dogs}

In order to assess whether cardiac pacing induces time-dependent changes in gene expression occurring over a period of $24 \mathrm{~h}$ which elapses between the pacing stimulus and the appearance of the delayed effect, the transcription of 29 genes were analyzed immediately, 6, 12 and 24 hours after cardiac pacing. Table 3 summarizes the gene expression changes observed at various time intervals after cardiac pacing. The results are expressed as ratios of gene expression data obtained from the time-matched sham-paced control hearts.

There were eight genes which were immediately up-regulated after the cessation of pacing. These genes encode HSP90, MnSOD, Bcl-2, PKC $\varepsilon$, ERK1, sGCa1, sGC $\beta 1$, sGC $\alpha 2$. There were six genes which exhibited early down-regulation following the pacing stimulus, such as CAT, casp3, casp9, GSK3 $\beta$ and MMP9. Of these early up- or down-regulated genes, MnSOD, PKCe, casp3 and casp9, GSK3 $\beta$ and MMP9 remained unchanged (i.e. up and down-regulated) at almost all time-points, whereas the others, like HSP90, ERK1, Bcl-2 and sGC isoforms, showed biphasic transcriptional changes; i.e. after the initial up-regulation these genes were down-regulated (mostly at 6h) but up-regulated again around 12 and 24h (Table 3). There were also genes, such as those encode NO producing enzymes eNOS, iNOS and the gap junction forming protein $\mathrm{Cx} 43$, which exhibited significant up-regulation only $12 \mathrm{~h}$ after the cessation of pacing (Table 3 ). Surprisingly, the expressions of genes responsible for the production of mitochondrial proteins, as well as Cox2, were not significantly altered. 


\begin{tabular}{|c|c|c|c|c|c|c|}
\hline Categories & Gene name & Accession & $\mathbf{P - 0 h} / \mathbf{S P}$ & P-6h/SP & P-12h/SP & P-24h/SP \\
\hline \multirow[t]{3}{*}{ heat shock proteins } & heat shock 27kDa protein (HSP27) & NM_001003295 & $0.50(0.01)$ & $0.36(0.07)$ & $0.92(0.21)$ & $1.08(0.37)$ \\
\hline & heat shock 70kDa protein (HSP70) & NM_006597 & $0.99(0.72)$ & $0.19(0.13)$ & $0.69(0.48)$ & $0.32(0.16)$ \\
\hline & heat shock 90kDa protein (HSP90) & NM_001017963.2 & $1.78(0.19)$ & $0.85(0.17)$ & $1.50(0.25)$ & $1.11(0.31)$ \\
\hline gap junctions & connexin $43(\mathrm{Cx} 43)$ & NM_001002951 & $1.43(0.18)$ & $0.40(0.10)$ & $2.20(0.44)$ & $1.15(0.28)$ \\
\hline \multirow[t]{2}{*}{ antioxidants } & catalase (CAT) & NM_001002984 & $0.17(0.13)$ & $0.25(0.12)$ & $0.89(0.70)$ & $0.87(0.46)$ \\
\hline & Mn superoxide dismutase (MnSOD) & NM_000636 & $2.30(0.46)$ & $1.80(0.26)$ & $1.61(0.15)$ & $2.02(0.50)$ \\
\hline \multirow[t]{2}{*}{ NO production } & endothelial nitric oxide synthase (eNOS) & NM_001003158 & $0.67(0.07)$ & $1.09(0.06)$ & $2.19(0.53)$ & $0.59(0.11)$ \\
\hline & inducible nitric oxide synthase (iNOS) & NM_001003186 & $1.47(0.45)$ & $1.15(0.22)$ & $2.43(0.27)$ & $0.99(0.21)$ \\
\hline \multirow[t]{4}{*}{ apoptosis } & apoptosis-related cysteine peptidase 3 (casp3) & NM_001003042 & $0.36(0.09)$ & $0.33(0.13)$ & $0.32(0.12)$ & $1.28(0.08)$ \\
\hline & apoptosis-related cysteine peptidase 9 (casp9) & XM_847070 & $0.18(0.16)$ & $0.15(0.11)$ & $0.32(0.05)$ & $1.23(0.22)$ \\
\hline & BCL2-associated X protein (BAX) & NM_001003011 & $0.72(0.28)$ & $0.32(0.02)$ & $0.74(0.38)$ & $1.15(0.22)$ \\
\hline & B-cell CLL/lymphoma 2 (Bcl2) & NM_001002949 & $2.78(0.99)$ & $0.45(0.15)$ & $1.62(0.54)$ & $2.66(1.02)$ \\
\hline \multirow[t]{9}{*}{ signal transduction } & protein kinase $\mathrm{C}$, alpha $(\mathrm{PKC} \alpha)$ & NM_002737 & $1.42(0.39)$ & $0.87(0.36)$ & $2.15(0.40)$ & $1.90(0.23)$ \\
\hline & protein kinase $\mathrm{C}$, delta $(\mathrm{PKC} \delta)$ & NM_001008716 & $1.05(0.01)$ & $0.57(0.14)$ & $1.44(0.32)$ & $1.31(0.23)$ \\
\hline & protein kinase $\mathrm{C}$, epsilon (PKC $\varepsilon$ ) & NM_005400 & $6.73(2.43)$ & $1.77(0.32)$ & $2.27(0.31)$ & $2.08(0.37)$ \\
\hline & glycogen synthase kinase 3 beta (GSK3 $\beta$ ) & NM_002093 & $0.37(0.10)$ & $0.34(0.08)$ & $0.71(0.30)$ & $0.44(0.09)$ \\
\hline & extracellular signal-regulated kinase 1 (ERK1) & NM_002746 & $2.32(0.37)$ & $0.49(0.24)$ & $0.72(0.42)$ & $2.47(0.78)$ \\
\hline & extracellular signal-regulated kinase 2 (ERK2) & NM_002745 & $0.98(0.35)$ & $0.95(0.36)$ & $1.26(0.66)$ & $0.59(0.34)$ \\
\hline & guanylate cyclase soluble, alpha $1(\mathrm{sGC} \alpha 1)$ & NM_001018035 & $1.71(0.14)$ & $1.44(0.26)$ & $1.12(0.21)$ & $2.44(0.16)$ \\
\hline & guanylate cyclase soluble, beta $1(\mathrm{sGC} \beta 1)$ & NM_001018034 & $2.97(0.53)$ & $2.51(0.64)$ & $1.27(0.19)$ & $2.60(0.51)$ \\
\hline & guanylate cyclase soluble, alpha 2 (sGCa2) & NM_000855 & $2.21(0.81)$ & $1.18(0.07)$ & $1.62(0.11)$ & $2.41(0.90)$ \\
\hline \multirow[t]{5}{*}{ mitochondria } & cytochrome c (CytC) & NM_001197045 & $1.05(0.25)$ & $0.85(0.21)$ & $0.79(0.22)$ & $1.00(0.54)$ \\
\hline & ATP synthase, Fo complex, subunit F6 & NM_001003703 & $1.48(0.14)$ & $0.93(0.30)$ & $0.64(0.05)$ & $0.51(0.09)$ \\
\hline & cytochrome c oxidase subunit Va (COX5A) & NM_004255 & $1.38(0.15)$ & $0.82(0.05)$ & $0.02(0.28)$ & $1.16(0.07)$ \\
\hline & NADH dehydrogenase $\mathrm{Fe}-\mathrm{S}$ protein2, 49kDa & NM_001166159 & $1.33(0.19)$ & $0.59(0.06)$ & $0.80(0.07)$ & $0.76(0.09)$ \\
\hline & NADH dehydrogenase $\mathrm{Fe}-\mathrm{S}$ protein $1,75 \mathrm{kDa}$ & NM_005006 & $1.05(0.18)$ & $0.65(0.16)$ & $0.46(0.08)$ & $0.52(0.07)$ \\
\hline \multirow[t]{3}{*}{ others } & matrix metalloproteinase 2 (MMP2) & NM_004530 & $0.63(0.19)$ & $0.65(0.09)$ & $1.04(0.18)$ & $0.73(0.02)$ \\
\hline & matrix metalloproteinase 9 (MMP9) & NM_001003219 & $0.06(0.08)$ & $0.17(0.04)$ & $1.08(0.38)$ & $0.59(0.31)$ \\
\hline & cyclooxygenase-2 (Cox2) & NM_001003354 & $0.19(0.09)$ & $0.28(0.14)$ & $0.87(0.41)$ & $0.27(0.15)$ \\
\hline
\end{tabular}

Table 3. Time-course changes in gene expression following cardiac pacing in dogs. The 29 genes examined were divided into different groups according to their functions. Genes with expression values lower than 0.5 or higher than 1.5 were considered to be down or up-regulated. Values are means \pm SD (indicated in brackets) of three parallel qRT-PCR reactions. (The values labeled with red indicate up-regulation while the data labeled with blue indicate down-regulation.) 
Some of the results summarized in Table 2 and Table 3 are also illustrated in figures (Figure 2, 3 and 4) by selecting those genes which have shown significant transcription alterations following cardiac pacing, and also after the 25 min of coronary artery occlusion and reperfusion may have essential functional role in the delayed cardioprotection afforded by preconditioning.

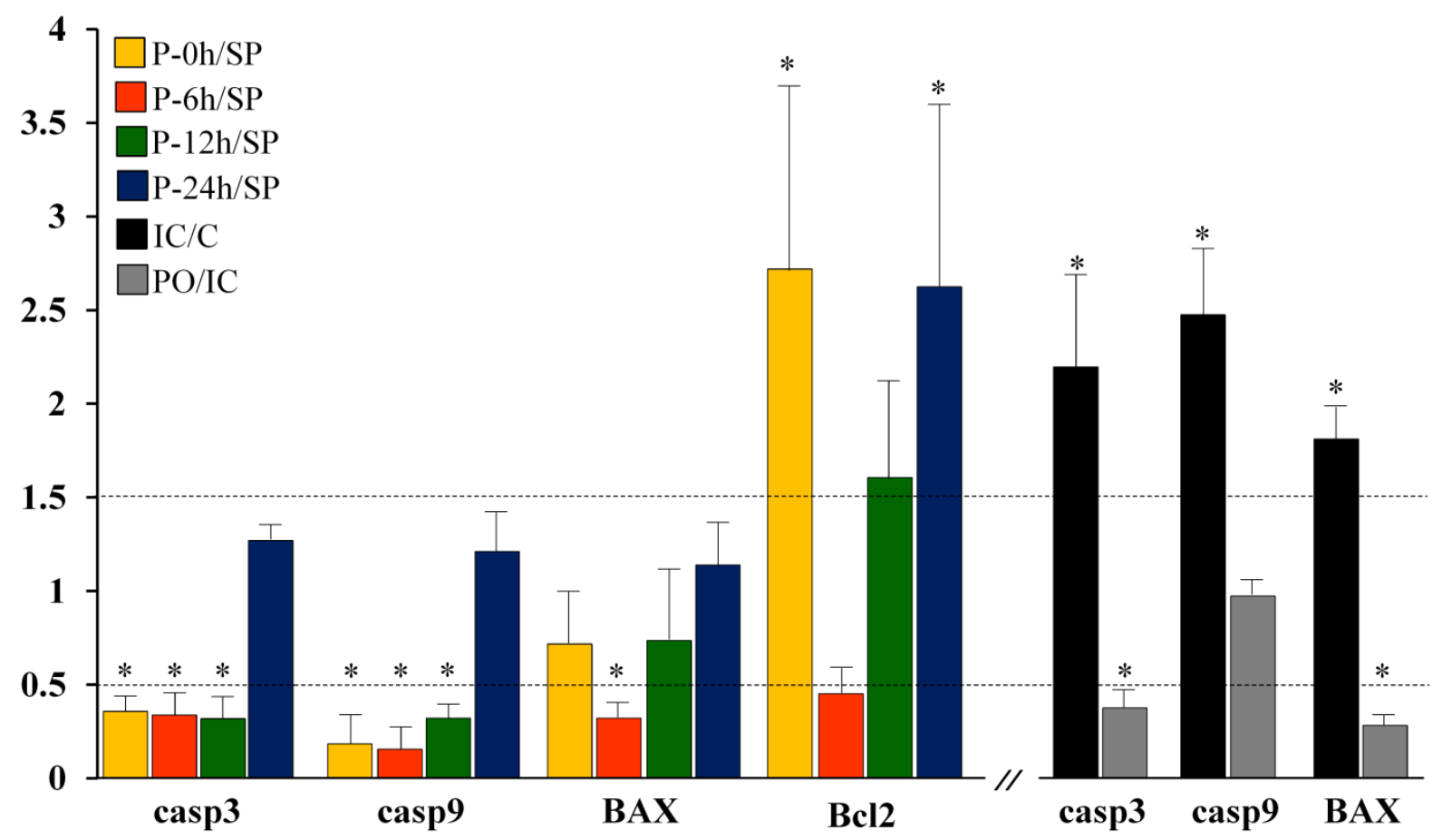

Figure 2. The effect of rapid cardiac pacing and ischemia/reperfusion on the expression of genes involved in apoptosis. Values are means $\pm \mathrm{SD}$. The lines indicate the interval between 0.5 and 1.5 fold of regulation.

Figure 2 shows that cardiac pacing significantly down-regulated the transcription of genes which are involved in apoptosis (casp3, casp9 and Bax) immediately (0h), 6 and 12h after cardiac pacing, but at $24 \mathrm{~h}$ the expression of these genes was not significantly different from the nonpaced controls. In contrast, pacing enhanced, at each time point, except $6 \mathrm{~h}$, the expression of gene encoding the anti-apoptotic Bcl-2 (Figure 2). Myocardial ischemia also altered the expression of casp3, casp9 and Bax. These exhibited significant up-regulation compared to the sham group and their expression ratios changed either to the opposite (casp3 and Bax) or showed no alteration (casp9) after cardiac pacing (Figure 2). 


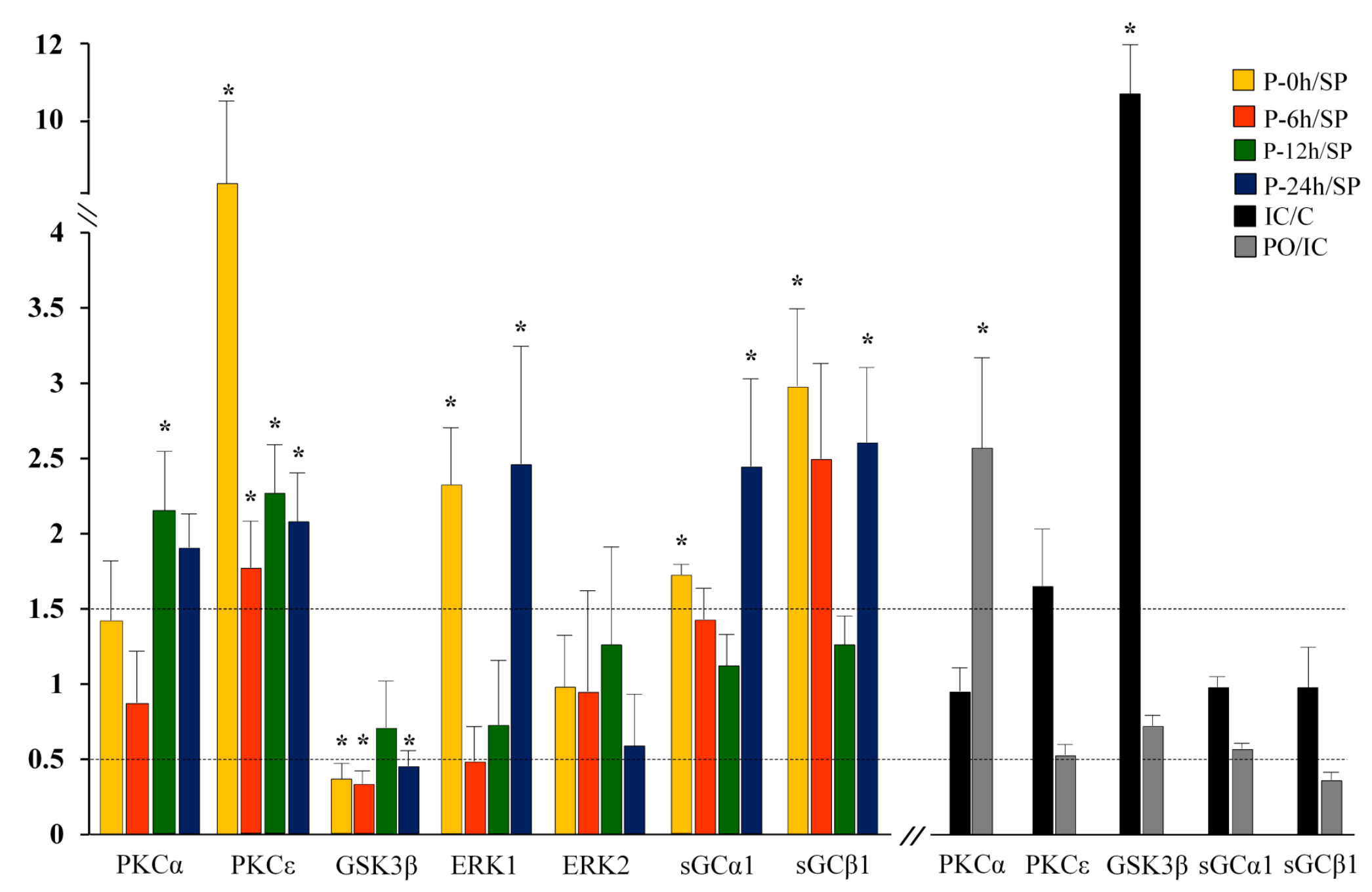

Figure 3. The effect of rapid cardiac pacing and ischemia/reperfusion on the expression of genes encoding proteins involved in signal transduction pathways. Values are means \pm SD. The lines indicate the interval between 0.5 and 1.5 fold of regulation. (Note: ERK1 and ERK2 were not involved in Study II.) 
The time-course pattern of genes encoding proteins involved in signal transduction showed large variation. Of these genes only PKC $\varepsilon$ exhibited enhanced transcription in response to rapid cardiac pacing at each time point. PKC $\alpha$ was only up-regulated at 12 and $24 \mathrm{~h}$ whereas, the expression of PKC $\delta$ remained virtually unchanged (Figure 3). ERK1 showed an early (0h) and late (24h) upregulation, while GSK3 $\beta$ was down-regulated at almost all the measured time points. Genes encoding the isoforms of sGC were significantly up-regulated immediately, and $24 \mathrm{~h}$ after the cessation of the pacing stimulus (Figure 3). In response to ischemia, GSK3 $\beta$ showed a significant down-regulation while the other genes were not altered. These genes in the PO group showed no significant changes except for PKC $\alpha$ which was up-regulated when compared to the ischemic controls.

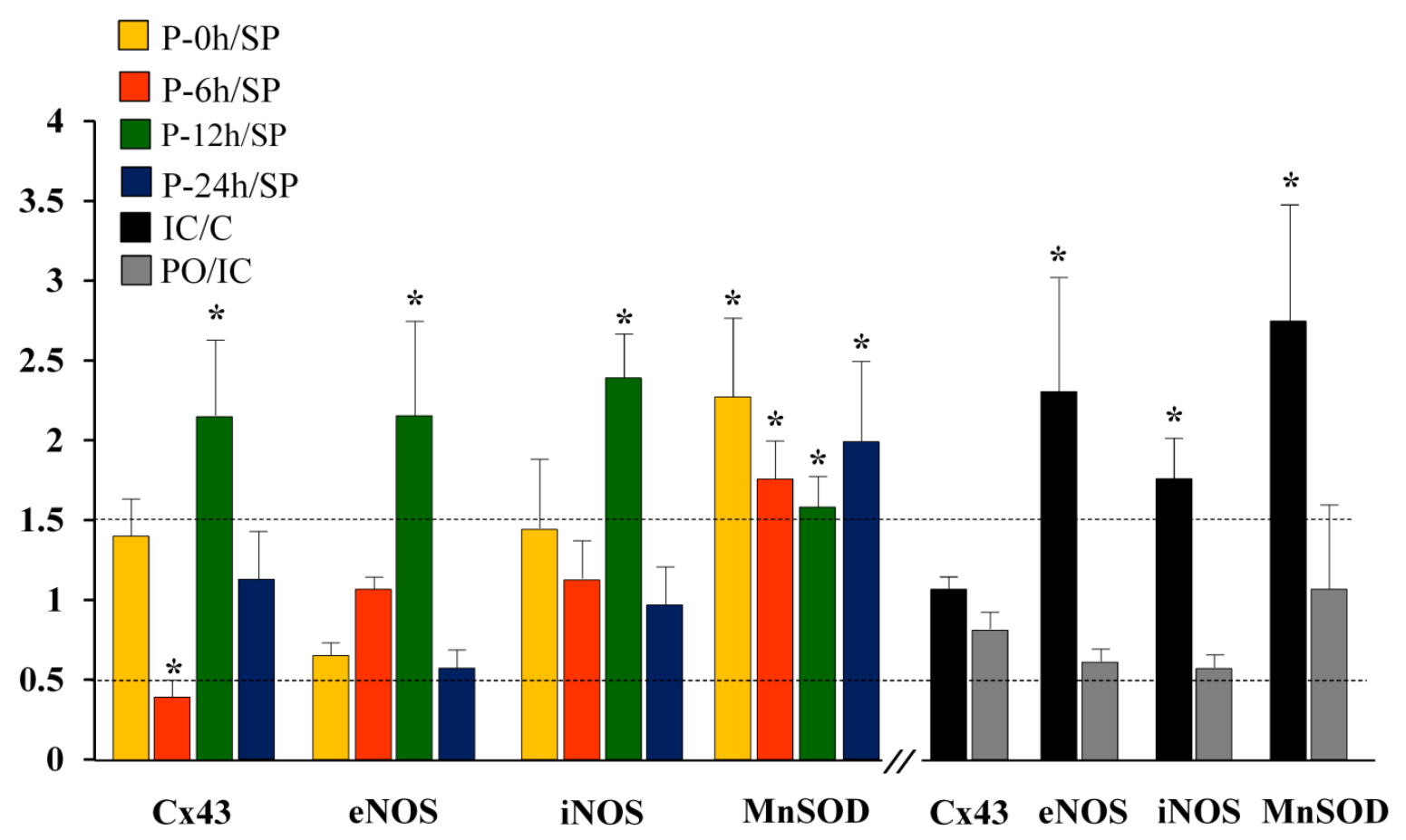

Figure 4. The time-course changes in expression of genes which encode eNOS, iNOS, MnSOD enzymes as well as $\mathrm{Cx43}$ and their alterations at the time of delayed PC. Values are means \pm SD. The lines indicate the interval between 0.5 and 1.5 fold of regulation. Myocardial ischemia up-regulated the expression of MnSOD, iNOS and eNOS but the relative expression ratios of these genes were not altered when rapid cardiac pacing was performed $24 \mathrm{~h}$ earlier. 
The genes responsible for the transcription of eNOS, iNOS were significantly up-regulated only $12 \mathrm{~h}$ after pacing. (Figure 4). In contrast, the mRNA expression of MnSOD was up-regulated at all time points. The transcription level of $\mathrm{Cx} 43$ down-regulated at $6 \mathrm{~h}$ but up-regulated $12 \mathrm{~h}$ after pacing and, as we have described previously, these changes in Cx43 gene expression were in association with arrhythmia generation resulting from ischemia and reperfusion [41].

\subsection{Time-course changes in eNOS protein content and activation}

We have performed experiments in which, using the sham-paced control and paced heart samples, the time course of eNOS protein content and activity were determined by Western blot analysis (Figure 6). The results clearly show that compared with the non-paced controls, in the paced dogs eNOS protein content was significantly increased only $24 \mathrm{~h}$ after the pacing stimulus (Figure 5a), whereas the activity of this enzyme (assessed by measuring the phosphorylated form) was increased twice; i.e. immediately and $24 \mathrm{~h}$ after pacing (Figure $5 \mathrm{~b}$ ).

A)
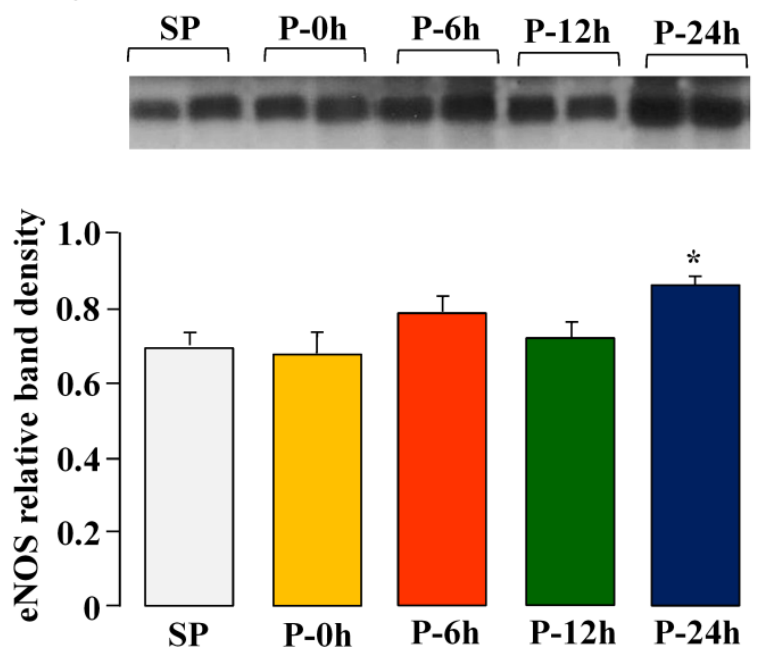

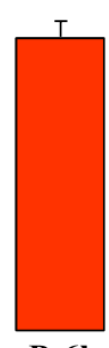

P-0h

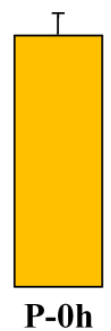

P-6h

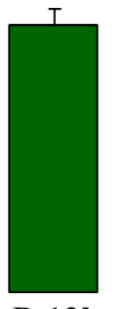

P-12h

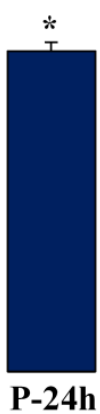

B)
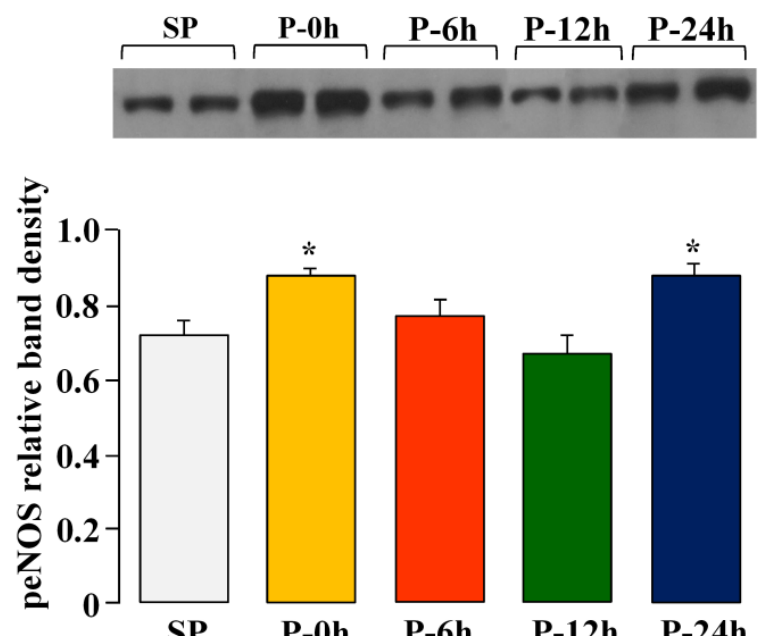

P-12h P-24h

Figure 5. Time-course changes in eNOS protein content (A) and activation (B) determined at various time intervals after rapid cardiac pacing by Western blot. Values are mean \pm S.E.M. ${ }^{*} \mathrm{P}<0.05$ vs. SP group (Bonferroni correction). 


\section{DISCUSSION}

\subsection{New findings}

I. We have identified 23 genes with altered expression induced by cardiac pacing in a large animal model of ischemia and reperfusion. Cardiac pacing resulted in an enhanced expression of 19 genes and lower expression of 4 genes. The genes with altered transcription rate encode transcription factors, ion channels and members of signal transduction pathways. Some of these, for example MEF2A or mAKAP, has been firstly demonstrated to be significantly up-regulated during the pacing induced protection.

II. We have proved that rapid right ventricular pacing is associated with altered expression of genes involved in the delayed protection. Forty-five genes were selected which have previously identified as mediators or important members of the PC induced cardioprotection. Out of these genes, six exhibited significant down-regulation and 16 showed up-regulation in response to myocardial ischemia when compared to the control dogs. Their expression ratios changed either to the opposite (11) or showed no alteration (10) in the PO group. Among these nNOS, HSP70, PKC $\alpha$, JNK1, GSK3 $\alpha$, GYS1, BDKRB1 showed up-regulation, and BAX, BAK and casp3 downregulation after rapid cardiac pacing.

III. We are the first to show that cardiac pacing induces time course changes in gene expression during the time interval which elapses between the PC stimulus and the appearance of the delayed protection. There were 8 genes which were up-regulated immediately after the cessation of pacing (HSP90, MnSOD, Bcl-2, PKCE, ERK1, sGCa1, sGC $\beta 1$, sGC $\alpha 2$ ) and there were 6 genes which exhibited an early down-regulation following the pacing stimulus (CAT, casp3, casp9, GSK3 $\beta$, MMP9 and Cox2). Some of these early up- or down-regulated genes remained unchanged (i.e. up and down-regulated, MnSOD, PKC $\varepsilon$, casp3 and casp9, GSK3 $\beta$ and MMP9) at almost each observed time-points, whereas others, like ERK1, Bcl-2 and sGC isoforms, showed biphasic transcriptional changes; i.e. after the initial up-regulation these genes were downregulated (mostly at $6 \mathrm{~h}$ ) but were up-regulated again around 12 and $24 \mathrm{~h}$. There were also genes, eNOS, iNOS and Cx43, which exhibited significant up-regulation only $12 \mathrm{~h}$ after the pacing stimulus. 
IV. We propose that an increase in eNOS protein expression and activity, besides the increased iNOS activation, may also play a role in NO production which mediates the late phase of the protection.

\subsection{Changes in transcription levels of different genes after delayed PC by cDNA microarray.}

In the last few years, cDNA microarrays [39, 48, reviewed by 40] or other large-scale expression profiling technologies, such as subtractive hybridization [36] or RDA [49] are increasingly used to determine transcriptional profiles induced by PC in different animal models. In order to understand the different genomic responses, the knowledge of cDNA sequences is required. Since commercial microarrays, printed with thousands of known cDNAs, are primary available for rodents (rats or mice) large scale genomic analysis have been performed in these animal models to investigate gene expression profiles occurring during ischemia and reperfusion or after preconditioning [37, 38, 39.]. Only few studies aimed to examine the preconditioning-induced genomic responses in large animals such as pigs and dogs. For example, in dogs, using cDNA RDA analysis, Zubakov et al. have found that genes involved in inflammatory response were highly up-regulated during the late phase of preconditioning [49]. In a porcine model, induction of genes encoding transcription factors, heat shock proteins, calcium-handling proteins and growth factors have been found in response to preconditioning [50].

Thus, one of the aims of these studies was to find a relationship between the antiarrhythmic effect and the gene expression changes that occur in dogs subjected to coronary artery occlusion and reperfusion $24 \mathrm{~h}$ after rapid cardiac pacing. To achieve this, microarray analysis was performed with 3200 cDNAs and the results were confirmed by qRT-PCR.

Among the genes examined, MEF2A showed significant up-regulation during the late phase of the protection when compared to the ischemic controls (Table1). The transcription factor encoded by this gene belongs to the MEF2 family which controls vascular development [51, 52]. The enhanced transcription of this gene supports those previous findings that ischemic PC induces angiogenesis through VEGF mediated signaling and that the target gene of this pathway is a transcription factor from the MEF2 family [53, 54]. Another gene, TGF $\beta 2$ also showed a higher expression at the time of the appearance of the late phase of the protection when compared to the ischemic controls (Table1). This is in accordance with a previous study in which four repetitive cycles of coronary artery occlusion have been used to stimulate vascular growth [55] and found 
that TGF $\beta$ was significantly up-regulated $48 \mathrm{~h}$ after this preconditioning stimulus. These findings might indicate that cardiac pacing induces processes which are involved in vascular growth.

Another gene which was significantly up-regulated following pacing was PDE4D9. This encodes an isoform of a phophodiesterase enzyme responsible for cAMP degradation in cardiac myocytes [56] (Table1). In rat isolated and perfused hearts, ischemic PC increased tissue cAMP level, which was normalized upon reperfusion, whereas PDE activity showed opposite changes; i.e. reduced during ischemia and increased following reperfusion [57]. Furthermore, the cAMPdependent PDE activities were higher throughout a $25 \mathrm{~min}$ sustained ischemia in the preconditioned than in control hearts and this was accompanied by a significantly less accumulation of cAMP in the PC hearts. The reduction in cAMP may play a role in the antiarrhythmic effect by decreasing the activity of the PKA and thereby by reducing calcium influx through L-type calcium channels. The role of cGMPs in the regulation of PDE4 phosphodiesterases is not clear either in the early or the delayed phase of protection. In rat isolated hearts, using cDNA microarray, a considerable induction in the expression of a cGMP phosphodiesterase (PDE9A1) has been found following preconditioning [39], suggesting that PDEs may play an important trigger and mediator role in the early and in the delayed cardioprotection.

Another gene that showed enhanced transcription during the delayed phase of the pacing-induced protection is mAKAP (Table1). This protein is an anchoring protein which connects cAMPbinding proteins, such as, PKA, EPAC1 and the phosphodiesterase PDE4D3 to form macromolecular complexes [58]. This complex plays an important role in the regulation of the cAMP-PKA signaling pathway by anchoring these proteins to different cell organelles. This of our finding is the first to demonstrate that the expression of an anchoring protein is altered after preconditioning. Similarly, genes encoding V1 and V2 receptors have not been examined in relation to PC. We have found that these genes were down-regulated after cardiac pacing and showed an enhanced expression in response to ischemia.

In summary, among the 3200 cDNAs that have been examined, only 10 genes showed altered expression in response to the acute ischemic and reperfusion insult, whereas 19 genes to rapid cardiac pacing. One of the reasons for these limited results might be that at the time of the experiments genome-wide chips were not available for large animals, such as dogs or pigs. Thus, we used the human cDNA library for the analysis of microarrays which certainly limits the number of positive signals in the gene expression analysis, despite the high homology between 
the human and canine genome. However, using a human cDNA microarray with 3200 genes we were able to follow the expression changes of more genes than those of the previous studies. Another limitation of the study is that the cDNA microarray analysis provides information only about the mRNA level of genes but it does not reflect the expression or the function of proteins that have certainly produced and possibly acted at the time of sampling. This might also explain that only a limited number of genes have been found with altered expression during the late phase of the protection induced by cardiac pacing.

The results of these previous studies have prompted us to perform further investigations, in which the time course changes of gene expression were analyzed during a $24 \mathrm{~h}$ period, which elapses between the preconditioning stimulus and the test ischemia. Also, some proteins for example Cx43 in a previous and eNOS in this current study were also examined to obtain information on their expression changes at the protein level due to cardiac pacing.

\subsection{Effects of rapid cardiac pacing on gene expression changes}

In this study, numerous genes were selected for RT-PCR analysis from various functional categories that had been previously shown to relate to the delayed protection (Table 2 and Table 3). Furthermore, this is the first study which has attempted to examine the sequence of gene expression changes following a PC stimulus.

Previous results from various animal models confirmed the involvement of NOS enzymes (iNOS; eNOS; nNOS), antioxidant enzymes (Cu/Zn-SOD; MnSOD; CAT), cyclooxygenases (COX1; COX2), and heat shock proteins (HSPs) in the delayed cardioprotective effect of preconditioning. Previous results suggested that the antioxidant factor MnSOD has a particular role both in the early and the delayed phase of protection [33, 59, 60]. The transcription of this gene was significantly enhanced in response to cardiac pacing at all the observed time points (Figure 4). Compared to the sham-paced and sham-operated controls, the expression of this gene was also significantly up-regulated after myocardial ischemia and it was not significantly altered by cardiac pacing (Figure 4). Das et al also found that repeated ischemia and reperfusion caused an immediate up-regulation in the expression of MnSOD in isolated buffer-perfused rat hearts [59]. MnSOD content was also increased with a peak at $24 \mathrm{~h}$ after four 5 min episodes of regional ischemia and reperfusion in canine myocardium [33]. This finding supports the proposed parallelism between the induction of MnSOD and the protection, although a direct evidence for a 
cause-and effect relationship between the up-regulation of MnSOD and the pacing-induced protection has not yet been established.

Interestingly, one of the other examined antioxidant factors CAT, was down-regulated at the early time points after cardiac pacing, and also after a $25 \mathrm{~min}$ period of ischemia preceded by overdrive pacing $24 \mathrm{~h}$ before (Table 2 and 3). This result is in contrast with other studies using isolated Langendorf-perfused hearts in which an enhanced transcription for this gene has been found [59, 60]. However, these results were not confirmed by in vivo studies; i.e. neither catalase in dogs [33] nor other antioxidant enzymes in conscious pigs [61] were up-regulated in the time of the delayed protection.

It is known that activation of signaling pathways is involved in the development of the early protection [8]. For example, adenosine, bradykinin, and opioids that are generated and released by brief preconditioning ischemic periods bind to GPCRs and lead to activation of the PI3K pathway and of its downstream targets, such as Akt or ERK [8]. Akt (also known as PKB) has a central role in the regulation of other proteins by phosphorylation [24]. Akt phosphorylates and thereby activates eNOS which thus produces nitric oxide, which is one of the key messenger molecules both in the early and the late survival pathways [62]. Furthermore, Akt can also inhibit target proteins through phosphorylation such as GSK3 $\beta$ and the proapoptotic BAD or casp3 and 9 which, result in the inhibition of apoptotic processes during ischemia and reperfusion [24]. It has been suggested that PKCe is also activated by the PI3kinase, possibly through the Akt-eNOSsGC mediated pathways [17]. ERK is also activated by PKCe [25] in response to a preconditioning stimulus and phosphorylates the proapoptotic factor BAD.

In our present studies, several members of the signaling pathways were examined to determine their alterations following cardiac pacing (time-dependent study) and also during ischemia and reperfusion in the time of the delayed cardioprotection. As mentioned above, several members of signaling pathways have been proposed to be activated by a PC stimulus, but little is known how the expression of these genes is changed before and during the late phase of the protection. There is a lack of information about the sequence of gene expression changes during that time interval, which elapses between the PC stimulus and the appearance of the delayed protection.

We have found that genes encoding PKCe, ERK1 and different isoforms of sGC were early upregulated after cardiac pacing (Figure 3). For example, the gene encoding PKCE was markedly expressed at all the observed time points and remained up-regulated during ischemia. The transcription of this gene was also increased (not significant) after the myocardial ischemia but it 
was not significantly altered at the time of the delayed phase of protection induced by pacing. Even so, the marked up-regulation of PKC $\varepsilon$ immediately and $24 \mathrm{~h}$ after the pacing stimulus might indicate a role in both phases of the antiarrhythmic protection. There is pharmacological evidence that the activation of and the following translocation of $\mathrm{PKC} \varepsilon$ is necessary for the development of late protection $[63,64]$.

The expression of genes encoding $\mathrm{sGC} \alpha 1$ and $\mathrm{sGC} \beta 1$ was not significantly altered either by ischemia in dogs subjected to a $25 \mathrm{~min}$ ischemia/reperfusion insult (PO vs. IC). However, these genes were changed following cardiac pacing in a biphasic pattern. They were immediately upregulated after the pacing stimulus (P-Oh vs. SP) after which they were either normalized or down-regulated. However, these genes were up-regulated again 12 or $24 \mathrm{~h}$ after pacing (Figure 3). The importance of sGC-mediated signaling pathway in the early protection was suggested in our previous study in which the administration of methylene blue completely abolished the early antiarrhythmic effect of ischemic preconditioning [10]. More recent studies, using ODQ a selective inhibitor of sGC, have confirmed the role of NO-sGC pathway in the early [65] and also in the late [66] phase of the protection. The present results which clearly show a biphasic transcriptional activation of $\mathrm{sGC} \alpha 1, \mathrm{sCG} \alpha 2$ and $\mathrm{sGC} \beta 1$ following cardiac pacing, provide a further support for the role of this pathway in both phases of the protection.

Another gene GSK3 $\beta$ which was markedly altered after cardiac pacing is one of the key members of the preconditioning-induced survival pathway [8]. The enzymatic activity of this kinase is inhibited by phosphorylation and by interaction with other proteins. Under normal conditions, GSK3 $\beta$ is active and usually inactivates its primed substrates. As a key kinase it integrates multiple signaling pathways, and regulates many cellular processes, such as it inhibits transcription factors and induces apoptosis [67]. It has been found that preconditioning by inhibiting GSK3 $\beta$ through phosphorylation, results in cardioprotection [68]. Signaling through Akt, PKC, PKA and ERK phosphorylates and therefore inhibits GSK3 $\beta$, which in turn reduces the phosphorylation and activation of different proteins, such as the pro-apoptotic BAX [69], or inhibits the opening and formation of the mPTPs [21]. In our study, the expression of GSK3 $\beta$ was markedly down-regulated at almost each time point in the paced dogs. Furthermore, pacing reduced GSK3 $\beta$ expression during ischemia compared with the unpaced controls in which the transcription of this gene was considerably increased (Figure 3). This and the previous results indicate that cardiac pacing keeps the expression of the cardioprotective kinases, such as PKCE, PKCa, ERK1, sGC $\alpha 1 / \beta 1$, up-regulated over a longer period of time whereas it down-regulates 
the transcription of GSK3 3 . These results suggest that pacing facilitates the survival pathways during the both phases of the protection and suppresses the expression of genes which are involved in the harmful consequences of ischemia/reperfusion.

It is well established that NO, released during a preconditioning stimulus, plays a trigger and mediator role in both the early and delayed phase of the protection [9, 30]. We have now provided further evidence for this by demonstrating a marked increase in the transcription of both eNOS and iNOS $12 \mathrm{~h}$ after cardiac pacing. Furthermore, this was the only time point when the expression of these genes was significantly up-regulated (Figure 4). This finding might have a particular importance, since previous studies in conscious rabbits have reported that the activity of eNOS and nNOS was increased only immediately after preconditioning, but it was not affected 24h later [45], whereas the transcription of iNOS was up-regulated only at the time of the late phase of the protection [32].

There is no doubt that iNOS expression and the resultant increase in NO generation is essential for the development of the delayed antiarrhythmic protection. We have pharmacological evidence for this using various, more or less selective inhibitors of iNOS [6, 29, 31, 44], which are all markedly attenuated or even abolished the delayed protection against arrhythmias resulted from cardiac pacing $[6,29,31]$ or heavy physical exercise $[44,70]$. Since, these inhibitors are not entirely selective for iNOS the role of eNOS-derived NO formation in the delayed phase of the protection can not be ruled out. To support this hypothesis we have performed additional experiments to measure eNOS protein content and activation (Figure 5). The results show that eNOS protein content was significantly increased in the paced dogs, whereas the activity of this enzyme was increased twice; i.e. immediately and $24 \mathrm{~h}$ after pacing (Figure $5 \mathrm{~b}$ ). Thus we suggest, like the others $[32,45]$ that the release of NO immediately after the preconditioning stimulus most likely results from the increased activation of eNOS. This NO by stimulating the transcript of iNOS and eNOS, that occurs in dogs $12 \mathrm{~h}$ after pacing, results in further NO generation and availability at the time of the delayed protection. However, in contrast with others [32, 45], we propose that an increase in eNOS protein expression and activity, besides the increased iNOS activation, may also play a role in NO production which mediates the late phase of the protection. There are studies that confirm that anti-apoptotic processes, such as deletion of apoptotic proteins [71] or increased expression of anti-apoptotic factors [72, 73] reduce the ischemia-reperfusion mediated cell death. Other results also demonstrate that PC attenuates apoptotic cell death by decreasing the transcription of the pro-apoptotic BAX [74] and by increasing the expression of 
the anti-apoptotic Bcl-2 [75]. The present results demonstrate that the anti-apoptotic Bcl-2 was mostly up-regulated (immediately, 12 and 24 after cardiac pacing), whereas genes encoding the pro-apoptotic BAX and members of the apoptotic caspase cascade were down-regulated at various time points. In the ischemic controls the pro-apoptotic genes were enhanced while in the paced dogs, subjected to coronary artery occlusion and reperfusion $24 \mathrm{~h}$ later, the pro-apoptotic genes were markedly down-regulated. These results demonstrate that cardiac pacing protects the heart against apoptotic cell death.

Rapid cardiac pacing also modified the expression of the gene encoding the main gap junction forming protein $\mathrm{Cx} 43$. It was down-regulated $6 \mathrm{~h}$ after rapid cardiac pacing and was up-regulated again at $12 \mathrm{~h}$. In our previous study we have found that pacing influenced the protein expression and the subcellular location of $\mathrm{Cx} 43$ [41]. According to these results, twelve hours after the pacing stimulus the protein content of $\mathrm{Cx} 43$ was decreased and this was preceded by a downregulation of mRNA at $6 \mathrm{~h}$. Also, the signals obtained from the Cx43-labeled immunofluorescence images showed that the ischemia-induced structural impairment of the intercalated discs was preserved after the pacing stimulus. Preconditioning also preserved gap junction permeability and $\mathrm{Cx} 43$ phosphorylation compared to the ischemic controls.

In summary, these results provide evidence for the first time that cardiac pacing induces timecourse dependent gene expression changes, which contribute to the appearance of the early and the late phase of the protection. We have found genes which were immediately altered after rapid cardiac pacing. These encode proteins that are already known to have a role in the early phase of protection. Some of these genes preserved their altered transcription over a $24 \mathrm{~h}$ time interval, whereas others showed a biphasic (early and late) activation pattern, indicating a role of these genes in the development of delayed phase of the antiarrhythmic protection. There were a few genes which were altered at later time points. For example, iNOS or eNOS were activated $12 \mathrm{~h}$ after the PC stimulus and these changes resulted in enhanced protein production at $24 \mathrm{~h}$, when the late phase usually appears. We are aware that changes in gene expression does not provide information about the protein content, but these present results provide evidence for a timedependent change in gene expression which occur between the PC stimulus and the appearance of the delayed protection. 


\section{REFERENCES}

1. Murry CE, Jennings RB, Reimer KA. Preconditioning with ischemia: a delay of lethal cell injury in ischemic myocardium. Circulation 1986; 74:1124-1136.

2. Végh Á, Komori S, Szekeres L, Parratt JR. Antiarrhythmic effect of preconditioning in anaesthetised dogs and rats Cardiovasc. Res. 1992; 26(5):487-95.

3. Cave AC. Preconditioning induced protection against post-ischaemic contractile dysfunction: characteristics and mechanisms. J Mol Cell Cardiol 1995; 27: 969-79.

4. Végh Á, Szekeres L, Parrat JR. Transient ishcaemia induced by rapid cardiac pacing resultsin myocardial preconditioning Cardiovasc. Res. 1991; 25(12):1051-3.

5. Kaszala K, Végh Á, Papp JGy, Parratt JR. Time course of the protection against ischemia and reperfusion induced ventricular arrhythmias resulting from brief periods of cardiac pacing. $\mathrm{J}$ Mol Cell Cardiol 1996; 28:2085-2095.

6. Kis A, Végh Á, Papp JG, Parratt JR. Repeated cardiac pacing extends the time during which canine hearts are protected against ischemia-induced arrhythmias: role of nitric oxide. J Mol Cell Cardiol 1999; 31:1229-1241.

7. Parratt J. Endogenous myocardial protective (antiarrhythmic) substances. Cardiovasc Res; 27: 693-702, 1993.

8. Murphy E, Steenbergen C. Mechanisms underlying acute protection from cardiac ischemia reperfusion injury. Physiol Rev 2008; 88:581-609.

9. Végh Á, Szekeres L, Parratt JR. Preconditioning of the ishaemic myocardium; involvement of the L-arginine nitric oxide pathway. Br J Pharmacol 1992; 107:648-652.

10. Végh Á, Papp JGy, Szekeres L, Parratt JR. The local intracoronary administration of methylene blue prevents the pronounced antiarrhythmic effect of ischemic preconditioning. Br J Pharmacol 1992; 107:910-911.

11. Duchen MR, McGuinness O, Brown LA, Crompton M. On the involvement of a cyclosporine A sensitive mitochondrial pore in myocardial reperfusion injury. Cardiovasc Res 1993;27:1790-1794. 
12. Gross GJ, Auchampach JA. Blockade of ATP-sensitive potassium channels prevents myocardial preconditioning in dogs. Circ. Res 1992;70:223-233

13. Grover GJ. Protective effects of ATP-sensitive potassium channel openers in models of myocardial ischaemia. Cardiovasc.Res 1994; 28:778-782.

14. Schulz R, Rose J, Heusch G. Involvement of activation of ATP-dependent potassium channels in ischaemic preconditioning in swine. Am. J. Physiol. 1994; 267:H1341-H1352.

15. Murata M, Akao M, O’Rourke B, Marban E. Mitochondrial ATP sensitive potassium channels attenuate matrix $\mathrm{Ca}^{+}$overload during simulated ischemia and reperfusion: possible mechanism of cardioprotection.Circ Res 2001; 89: 891- 898.

16. Liu Y, Gao WD, O'Rourke B, Marban E. Synergistic modulation of ATP-sensitive $\mathrm{K}^{+}$ currents by protein kinase $\mathrm{C}$ and adenosine. Implications for ischemic preconditioning. Circ Res 1996; 78:443-454.

17. Costa AD, Garlid KD, West IC, Lincoln TM, Downey JM, Cohen MV, Critz SD. Protein kinase $\mathrm{G}$ transmits the cardioprotective signal from cytosol to mitochondria. Circ Res 2005; 97: $329-336$.

18. Pain T, Yang XM, Critz SD, Yue Y, Nakano A, Liu GS, Heusch G, Cohen MV, Downey JM. Opening of mitochondrial K(ATP) channels triggers the preconditioned state by generating free radicals. Circ Res 2000; 87:460 - 466.

19. Griffiths EJ, Halestrap AP. Protection by cyclosporin A of ischemia/reperfusion induce damage in isolated rat hearts. J Mol Cell Cardiol 1993; 25: 1461-1469.

20. Halestrap AP, Clarke SJ, Javadov SA. Mitochondrial permeability transition pore opening during myocardial reperfusion-a target for cardioprotection. Cardiovasc Res 2004; 61: 372 385.

21. Juhaszova M, Zorov DB, Kim SH, Pepe S, Fu Q, Fishbein KW, Ziman BD, Wang S, Ytrehus $\mathrm{K}$, Antos CL, Olson EN, Sollott SJ. Glycogen synthase kinase-3 beta mediates convergence of protection signaling to inhibit the mitochondrial permeability transition pore. J Clin Invest 2004; 113:1535-1549.

22. Baines CP, Song CX, Zheng YT, Wang GW, Zhang J, Wang OL, Guo Y, Bolli R, Cardwell EM, Ping P. Protein kinase $\mathrm{C}$ epsilon interacts with and inhibits the permeability transition pore in cardiac mitochondria. Circ Res 2003; 92: 873-880. 
23. Imahashi K, Schneider MD, Steenbergen C, Murphy E. Transgenic expression of Bcl-2 modulates energy metabolism, prevents cytosolic acidification during ischemia, reduces ischemia/reperfusion injury. Circ Res 2004; 95:734-741.

24. Fayard E, Tintignac LA, Baudry A, Hemmings BA. Protein kinase B/Akt at a glance. J Cell Sci 2005; 118:5675-5678.

25. Baines CP, Zhang J, Wang GW, Zheng YT, Xiu JX, Cardwell EM, Bolli R, Ping P. Mitochondrial PKC epsilon and MAPK form signaling modules in the murine heart: enhanced mitochondrial PKC epsilon-MAPK interactions and differential MAPK activation in PKC epsilon-induced cardioprotection. Circ Res 2002; 90: 390 -397.

26. Cinca J, Warren M, Carreno A, Tresánchez M, Armadans L, Gómez P, Soler-Soler J. Changes in myocardial electrical impedance induced by coronary artery occlusion in pigs with and without preconditioning: correlation with local ST-segment potential and ventricular arrhythmias. Circulation 1997; 96:3079-3086.

27. Schulz R, Heusch G. Connexin43 and ischaemic preconditioning. Adv. Cardiol. 2006; 42:213-227.

28. Bolli R. The late phase of preconditioning. Circ Res 2000; 87:972-983.

29. Végh Á, Papp JGy, Parratt JR. Prevention by dexamethasone of the marked antiarrhythmic effects of preconditioning induced $20 \mathrm{~h}$ after rapid cardiac pacing. Br. J. Pharmacol. 1994; 113:1081-1082.

30. Bolli R, Manchikalapudi S, Tang XL, Takano H, Qiu Y, Guo Y, Zhang Q, Jadoon AK. The protective effect of late preconditioning against myocardial stunning in conscious rabbits is mediated by nitric oxide synthase. Evidence that nitric oxide acts both as a trigger and as a mediator of the late phase of ischemic preconditioning. Circ Res 1997; 81:1094-1107.

31. Kis A, Végh Á, Papp JGy, Parratt JR. Pacing-induced delayed protection against arrhythmias is attenuated by aminoguanidine, an inhibitor of nitric oxide synthase. Br J Pharmacol 1999; 127:1545-1550.

32. Jones WK, Flaherty MP, Tang X-L, Takano H, Qui Y, Banerjee S, Smith T, Bolli R. Ischemic preconditioning increases iNOS transcript levels in conscious rabbits via a nitric oxidedependent mechanism. J Mol Cell Cardiol 1999; 31:1469-1481. 
33. Hoshida S, Kuzuya T, Fuji H, Yamashita N, Oe H, Hori M, Suzuki K, Taniguchi N, Tada M Sublethal ischemia alters myocardial antioxidant activity in canine heart. Am J Physiol 1993; 264:H33-H39.

34. Baxter GF, Goma FM, Yellon DM. Involvement of protein kinase $\mathrm{C}$ in the delayed cytoprotection following sublethal ischemia in rabbit myo-cardium. Br J Pharmacol. 1995; $115: 222-224$.

35. Imagawa J, Baxter GF, Yellon DM. Genistein, a tyrosine kinase inhibitor, blocks the "second window of protection" 48 hours after ischemic precon-ditioning in the rabbit.J Mol Cell Cardiol. 1997; 29:1885-1893.

36. Depre C, Tomlinson JE, Kudej RK, Gaussin V, Thompson E, Song-Jung Kim, Vatner DE, Topper JN, Vatner SF. Gene program for cardiac cell survival induced by transient ischemia in conscious pigs. Proc Natl Acad Sci U S A. 2001; 98(16):9336-41.

37. Simkhovich, B. Z., Abdishoo, S., Poizat, C., Hale, S. L., Kedes, L. H., Kloner, R. A. Gene activity changes in ischemically preconditioned rabbit heart gene: discovery array study. Heart Disease 2002; 2:63-69.

38. Simkhovich, B. Z., Marjoram, P., Poizat, C., Kedes, L., Kloner, R. A. Brief episode of ischemia activates protective genetic program in rat heart: a gene chip study. Cardiovasc. Res. 2003; 59:450-459.

39. Ónody A, Zvara A, Hackler L Jr, Vígh L, Ferdinandy P, Puskás LG. Effect of classic preconditioning on the gene expression pattern of rat hearts: a DNA microarray study. FEBS Lett $2003 ; 536: 35-40$.

40. Das DK, Maulik N. Cardiac genomic response following preconditioning stimulus. Cardiovasc Res 2006; 70:254 - 263.

41. Gönczi M, Kovács M, Seprényi G, Végh Á. The involvement of gap junctions in the delayed phase of the protection induced by cardiac pacing in dogs. Clin Sci (Lond). 2012; 123:39-51.

42. Kaszala K, Végh Á, Papp JGy, Parratt JR. Modification by bradykinin B2 receptor blockade of protection by pacing against ischemia-induced arrhythmias. Europaen Journal of Pharmacology 1997; 328:51-60. 
43. Végh Á, Parratt JR. A common mechanism in the protective effects of preconditioning, cardiac pacing and physical exercise against ischemia and reperfusion-induced arrhythmias. Exp. Clin Cardiol 2005; 10(3):200-205.

44. Hajnal Á, Nagy O, Litvai Á, Papp JGy, Parratt JR, Végh Á. Nitric oxide involvement in the delayed antiarrhythmic effect of treadmill exercise in dogs. Life Sciences 2005; 77:19601971.

45. Xuan Y-T, Tang X-L, Qiu Y, Banerjee S, Takano H, Han H, Bolli R. Biphasic response of cardiac NO synthase isoforms to ischemic preconditioning in conscious rabbits. Am J Physiol Heart Circ Physiol 2000; 279:H2360-H2371.

46. Walker, M.J.A., Curtis, M.J., Hearse, D.J., Campbell, R.W.F., Janse, M.J., Yellon, D.M., Cobbe, S.M., Coker, S.J., Harness, J.B., Harron, D.W., Higgins, A.J., Julian, D.G., Lab, M.J., Manning, A.S., Northover, B.J., Parratt, J.R., Riemersma, R.A., Riva, E., Russell, D.C., Sheridan, D.J., Winslow, E., Woodward, B. The Lambeth Conventions: guidelines for the study of arrhythmias in ischemia, infarction, and reperfusion. Cardiovasc. Res. 1988; 22:447455 .

47. Fehér 1Z, Kálmán J, puskás, LG, Gyülvészi G, Kitajka K, Penke B, Palotás M, Samarova E. I, Molnár J, Zvara A, Matin K, Bódi N, Hugyecz M, Pákáski M, Bjelik A, Juhász A, Bogáts G, Janka Z, Palotás A. Impact of haloperidol and risperidone on gene expression profile in the rat cortex. Neurochem. Int. 2005; 47:271-280.

48. Ah-Mee Park H, Nagase S, Vinod K, Suzuki YJ. Acute intermittent hypoxia activates myocardial cell survival signaling. Am J Physiol Heart Circ Physiol 2006; 292:H751-H757.

49. Zubakov, D, Hoheisel, J. D., Kluxen, F. W., Brandle, M., Ehring, T., Hentsch, B., Frohme, M. Late ischemic preconditioning of the myocardium alters the expression of genes involved in inflammatory response. FEBS Lett. 2003; 547:51-55.

50. Deindl, E., Schaper, W. Gene expression after short periods of coronary occlusion. J. Mol. Cell. Biochem 1998; 186:43-51.

51. Qing Wang Molecular genetics of coronary artery disease Curr Opin Cardiol. 2005; 20(3):182-188.

52. Potthoff MJ, Olson EN. MEF2: a central regulator of diverse developmental programs Development 2007; 134:4131-4140. 
53. Maiti D, Xu Z, Duh EJ. Vascular endothelial growth factor induces Mef2C and Mef2dependent activity in endothelial cells. IOVS 2008; 49:3640-3648.

54. Fukuda S, Kaga S, Sasaki H, Zhan L, Zhu L, Otani H, Kalfin R, Das DK, Maulik N. Angiogenic signal triggered by ischemic stress induces myocardial repair in rat during chronic infarction.J. Mol. Cell. Cardiol. 2004; 36,547-559.

55. Mathur P, Kaga S, Zhan 1, Das DK, Maulik N. Potential candidates for ischemic preconditioning-associated vascular growth pathways revealed by antibody array. Am. J Physiol. Heart Circ. Physiol. 2005; 288, h3006-h3010.

56. Oleg E. Osadchii. Myocardial phosphodiesterases and regulation of cardiac contractility in health and cardiac disease. Cardiovasc Drugs Ther 2007; 21:171-194.

57. Lochner A, Genade S, Tromp E, Opie L, Moolman J, Thomas S, Podzuweit T. Role of cyclic nucleotide phosphodiesterases in ischemic preconditioning. Molecular and Cellular Biochemistry 1998; 186, 169-175.

58. Kimberly L, Dodge-Kafka Kapiloff MS. The mAKAP signaling complex: integration of cAMP, calcium, and MAP kinase signaling pathways. Eur. J. Cell. Biol. 2006; 85,593-602.

59. Das DK, Engelman RM, Kimura Y. Molecular adaptation of cellular defences following preconditioning of the heart by repeated ischemia. Cardiovasc Res 1993; 27:578-84.

60. Sergeev P, da Silva R, Lucchinetti E, Zaugg K, Pasch T, Schaub MC, Zaugg M Triggerdependent gene expression profiles in cardiac preconditioning: evidence for distinct genetic programs in ischemic and anesthetic preconditioning. Anesthesiology 2004; 100:474 - 488.

61. Tang X-L, Qiu Y, Turrens JF, Sun J-Z, Bolli R Late preconditioning against stunning is not mediated by increased antioxidant defenses in conscious pigs. Am J Physiol 1997; 273:H1631-H1657.

62. Fulton D, Gratton JP, McCabe TJ, Fontana J, Fujio Y, Walsh K, Franke TF, Papapetropoulos A, Sessa WC. Regulation of endothelium-derived nitric oxide production by the protein kinase Akt. Nature. 1999; 399:597-601.

63. Baxter GF, Goma FM, Yellon DM. Involvement of protein kinase C in the delayed cytoprotection following sublethal ischaemia in rabbit myo-cardium.Br J Pharmacol 1995; 115:222-224. 
64. Ping P, Zhang J, Qiu Y, Tang X-L, Manchikalapudi S, Cao X, Bolli R. Ischemic preconditioning induces selective translocation of protein kinase $\mathrm{C}$ isoforms $\varepsilon$ and $\eta$ in the heart of conscious rabbits without subcellular redistribution of total protein kinase $\mathrm{C}$ activity. Circ Res. 1997; 81:404-414.

65. Lochner A, Marais E, Du Toit E, Moolman J. Nitric oxide triggers classic ischemic preconditioning. Ann NY Acad Sci 2002; 962:404-414.

66. Kodani E, Xuan YT, Takano H, Shinmura K, Tang XL, Bolli R. Role of cyclic guanosine monophosphate in late preconditioning in conscious rabbits. Circulation 2002; 105:30463052 .

67. Richard S. Jope and Gail V.W. Johnson The glamour and gloom of glycogen synthase kinase3 TRENDS in Biochemical Sciences 2004; 29(2):95-102.

68. Tong H, Imahashi K, Steenbergen C, Murphy E. Phosphorylation of glycogen synthase kinase-3beta during preconditioning through a phosphatidylinositol-3-kinase-dependent pathway is cardioprotective. Circ. Res 2002; 90:377-379.

69. Linseman DA, Butts BD, Precht TA, Phelps RA, Le SS, Laessig TA. Glycogen synthase kinase-3 $\beta$ phosphorylates Bax and promotes its mitochondrial localization during neuronal apoptosis. J Neurosci 2004; 24: 9993 - 10002.

70. Babai L, Szigeti Z, Parratt JR, Végh Á. Delayed cardioprotective effects of exercise in dogs are aminoguanidine sensitive: possible involvement of nitric oxide. Clin Sci 2002; 102:435445.

71. Hochhauser E, Kivity S, Offen D, Maulik N, Otani H, Barhum Y, Pannet H, Shneyvays V, Shainberg A, Goldshtaub V, TobarA, Vidne BA. Bax ablation protects against myocardial ischemia-reperfusion injury in transgenic mice. Am J Physiol Heart Circ Physiol 2003; 284:H2351-H2359.

72. Imahashi K, Schneider MD, Steenbergen C, Murphy E. Transgenic expression of Bcl-2 modulates energy metabolism, prevents cytosolic acidification during ischemia, reduces ischemia/reperfu-sion injury. Circ Res 2004; 95:734-741.

73. Chen Z, Chua CC, Ho YS, Hamdy RC, Chua BH. Overexpression of Bcl-2 attenuates apoptosis and protects against myocardial I/R injury in transgenic mice. Am J Physiol Heart Circ Physiol 2001; 280:H2313-H2320. 
74. Nakamura M, Wang NP, Zhao ZQ, Wilcox JN, Thourani V, Guyton RA, Vinten-Johansen J. Preconditioning decreases Bax expression, PMN accumulation and apoptosis in reperfused rat heart. Cardiovasc Res 2000; 45:661-670.

75. Maulik N, Engelman RM, Rousou JA, Flack JE 3rd, Deaton D, Das DK. Ischemic preconditioning reduces apoptotosis by upregulating anti-death gene Bcl-2. Circulation 1999; 100:11369-11375. 


\section{ACKKNOWLEDGEMENTS}

I would like to thank Professor András Varró for providing the facilities to carry out my studies in the Department of Pharmacology and Pharmacotherapy, University of Szeged.

I would like to express my gratitude to my supervisor Professor Ágnes Végh for her guidance and help in my experimental studies and also for giving me many advices for preparing the manuscripts for publication.

I am very grateful to our research partner and friend Dr. György Seprényi for providing me the facilities for our molecular experiments in the Department of Medical Biology and also for his help and understanding regarding any experimental or personal problems.

I would like to thank Dr. László Puskás and Dr. Ernő Zádor for that I could carry out some parts of the molecular studies in their laboratories.

I also thank Erika Bakó, Irén Biczók for their technical assistance both during the in vivo and in vitro experiments. I also need to thank my colleagues and friends Dr. Rita Papp and Márton Gönczi for their help. I learned a lot during our brainstorming about how to or how not to perform an experimental study.

A special thank goes to my family for giving me strength during my studies and I also would like to thank Tamás for his endless support and for motivating me whenever my enthusiasm was lessened.

"SCIENCE: a way of finding things out and then making them work. Science explains what is happening around us the whole time. So does RELIGION, but science is better because it comes up with more understandable excuses when it's wrong."-Terry Pratchett, Wings (1997) 


\section{ANNEX}

\section{Reprints of full Papers}

1. Kovács M, Papp R, Varga-Orvos Z, Ménesi D, Puskás LG, Végh A. Changes in gene expression following cardiac pacing-induced delayed cardioprotection in the canine heart. Acta Biol Hung. 2010 Dec;61(4):434-48.

2. Mária Kovács, Márton Gönczi, Edina Kovács, Ágnes Végh. Time course analysis of cardiac pacing-induced gene expression changes in the canine heart. Mol Cell Biochem. 2013 Jan;372(1-2):257-66. doi: 10.1007/s11010-012-1467-8. 